ㄷ)
SportR Xiv
Part of the Society for Transparency,

\title{
Education under the \\ state of ISIS: What \\ lessons can be \\ learned from the \\ Physical Education Curriculum?
}

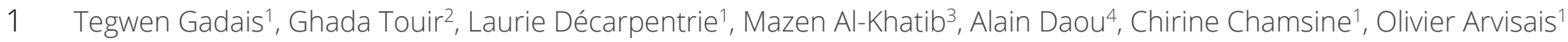

2 'University of Quebec in Montreal (UQÀM), Montreal, Canada

32 2U Concordia University, Montreal, Canada

$4 \quad{ }^{3}$ Al Quds University, Jerusalem, Cisjordan

$5 \quad{ }^{4}$ American University of Beirut, Beirut, Lebanon

7 POSTPRINT

8 To cite this article, please use this reference:

9 Gadais, T., Touir, G., Décarpentrie, L., Khatib, M. Daou, A., Chamsine, C. \& Arvisais, O. (2022). Education under ISIS: a content 10 analysis of the Physical Education Curriculum. Frontiers, Leadership in Education, 7:854413. 11 https://doi.org/10.3389/feduc.2022.854413 


\section{SportR Xiv}

Part of the Society for Transparency, Openness and Replication in

Kinesiology (STORK)

@)우

\section{Preprint}

not peer reviewed

\section{$12 \quad$ ABSTRACT}

13 This study focused on what lessons can be learned from the Physical Education Curriculum under the reign of 14 Islamic State of Iraq and Syria (ISIS)? We conducted an unprecedented analysis of ISIS primary school physical 15 education curriculum. The research objective focused on describing and analyzing the context and philosophy 16 of the document as well as its content (calligraphy, didactic, pedagogy, learning assessment, among others). We 17 also analyzed the general scientific quality of the curriculum of physical education targeting fitness preparation by the instructor in charge of the education of the youth. In addition, our analysis focused on the philosophical and contextual issues of the manual. Findings revealed an incomplete and a rapidly developed textbook where several essential elements related to pedagogy, didactics, learning and assessment were missing or inconsistent. The logic of military preparation under the guise of preparing the student's physical condition was an important finding without being explicitly mentioned. Integration of religious content was present without being affirmed in the content of the lessons. We argue that the ISIS physical education curriculum appears to be committed to an absolutist/theocratic ideological or propaganda program that, among other things,

25 promotes the preparation of the future soldiers of the ISIS army. Recommendations about secularization and the reconstruction of post-ISIS education systems are formulated. 


\section{Background}

Between 2014 and 2017, the Islamic State of Iraq and Syria (ISIS) has taken possession of several territories and regions in Iraq and Syria. It has implemented its ideas and ways of functioning. Furthermore, it has even proposed an educational corpus for the use of school teachers. In collaboration with humanitarian actors on the ground, we had access to several educational materials that have been put in place by the Islamic group. We conducted a series of analysis about the documents to better understand the group's intentions through education (Arvisais \& Guidère, 2020a), but also, to propose alternatives and recommendations to humanitarian workers and actors who are currently working in the field since the withdrawal of the armed group.

This specific study focused on what lessons can be learned from the Physical Education Curriculum under ISIS? We conducted an unprecedented analysis of ISIS primary school physical education curriculum. Based on a, so called, teacher's manual, the research objectives focus on describing and analyzing the general quality of the document, in particular: 1. Philosophy of the manual, 2. Calligraphy and semiology and 3. Content analysis on didactic, pedagogy, and learning, in order to understand ISIS intentions in this war-torn context.

\section{Using Sport and Physical Education to Serve Politics or Military Purposes}

Reviewing literature about the subject shows that little research on the topic has been done. Therefore, in the contemporary context of fight against terrorism, it seems relevant to consider three fields of scientific literature related to sport or physical education: a) using sport to spread ideologies, b) sport and physical education under totalitarian regimes and c) recruiting child soldiers.

Using Sport to Spread Ideologies

On historical and sociological perspectives, many relationships exist between specific ideologies and sport. Hoberman (1984) observed, "The idea that sport is somehow an intrinsically political phenomenon has never been explained. In fact, sport is less known for its political character than for its legendary effects" (p.1). Indeed, the influence on and/or relevance to sport of political ideologies varies enormously. Bairner (2017) advanced three main perspectives where sport or physical education can be used to vehicle ideologies. First, sport as a repository of ideological thinking, meaning political ideologies such as conservatism, liberalism and socialism, use their relation to sport to reflect as it does some key ideological elements such as spread 
communism in China (Hong \& Xiaozheng, 2002) or division and reunification in between countries (Merkel, 2009). Second, sport could also be a product of ideological thinking as communism, fascism/national socialism and nationalism for instance (Bairner, 2017; Galily, 2007 Sport or physical education has been used to train and represent a model or the identity (Sugden \& Tomlinson, 1998) that the political group wants to achieve. Third, sport is used as a site for aspirational ideological thinking such as feminism or environmental movements. The last category recognizes that those movements also seek to exert influence but in rather different ways. In the case of some ideologies, the degree of influence is relatively difficult to detect although the extent to which the core values of these ideologies are reflected in sport is of great significance. However, some ideologies have sought to directly affect the ways in which sport is organized and played (Gilchrist \& Holden, 2011; Grix, 2016).

\section{Sport and Physical Education Under Totalitarian Regimes}

Previous studies on history of sport or physical education have presented hypotheses and arguments about how and why ISIS could decide to use the education of the bodies. Indeed throughout history, several totalitarian regimes have sometimes tried to use sports (in various forms such as competitions, training, Olympic games), and physical education (the academic discipline) as an instrument to control and dominate but also to train and discipline subjects according to their ambitions of power (Guttmann, 2003). For example, in Germany, Italy and Spain, the political leaders namely Hilter, Mussolini and Franco, first had to be convinced of the power of sport to boost their international prestige (Guttmann, 2003). As noted by Boltz (2017), fascist movements were obsessed with changing the habits of the population and with training of athletes who would be loyal to the fascist cause. In their totalitarian system, education was the key to the implementation of the Revolution and the New Man was the result of fascist education, which laid as much emphasis on physical as on intellectual development. Changing minds and bodies for building a New Man were the main strategy used by the regimes (Bolz, 2008). Then, sport or physical education was used to share a theological vision of history, insofar as they conceived the history of mankind as a succession of phases, the aim of which was the holiest organization of society according to fascist principles (Gentile, 2013).

Gentile (2013) also noted that the conception of history and the use of the past were central to fascist ideologies, as in the end all the efforts served to establish these new "ideal" societies with unlimited ambitions regarding nations, race and international domination (Bolz, 2017; Krüger \& Murray, 2010). The alliance between totalitarianism and sport was not immediate and came gradually, as best illustrated by the 1934 football World Cup in Italy and the 1936 Berlin Olympics (Grix, 2013). The relationship between totalitarianism and sport 
emphasizing mass participation and preparing top-level athletes had a twofold aim. The propaganda and megaevents gave the people a sense of belonging to the community and convinced them of the validity of the fascist ideology. Also, impressive displays and successful sports results were presented to foreign observers as achievements of the fascist regimes and helped them to strengthen their diplomatic ideas. It is undeniable that fascism promoted sport and used it for its own political and ideological purposes. Sport was of interest to fascist movements because it gave their ideologies a forum where they could visibly concretize their social and possibly racial plans. In return, the sports movement benefited from it to some extent and some sports leaders saw the new regimes as opportunities for sport (Houlihan \& White, 2002).

Complementary, authors also demonstrated how physical education was instrumented to serve military ideas and soldiers training in France (Arnaud, 1991; Sarremejane, 2006). In a pre-World War I context and in between the two World Wars, physical education was placed under the control of the Ministry of the Army with the vocation of future soldiers' recruitment, preparation and training. This was possible because of a special context where conflict between nations in Europe was imminent (J. Saint-Martin, 2006). Now, it seems interesting to see how ISIS decided to organize its physical education curriculum, given the context in which it was implemented in Iraq and Syria. It also seems relevant to understand whether their intentions and operating structures were similar or different from previous totalitarian regimes in history. Finally, another hypothesis to explore is the possible use of a physical education curriculum for recruiting and training child soldiers.

\section{Recruiting Child Soldiers}

Around the world, UNICEF (2018) estimates that nearly 250 million children are growing up in torn regions and countries affected by conflict. Nearly 125 million of them are directly affected by violence (Charland, Arvisais, Cyr, \& Gadais, 2017). Sadly, Iraq (since 2003) and Syria (since 2011) have ranked high on torn and violent regions. In Iraq as well as in Syria, children have been bearing witness to the horrors of civil war mass terrorism, the death of loved ones, injury and amputation for many years. They also experience all sorts of violence: displacement, kidnapping, human trafficking, and sexual mutilation. Given their surroundings, children in such places often find their education interrupted whether by bombings that destroy schools or by unexploded ordnance and mines. Girls' education is also frequently halted by child marriage, while boys are forced to enlist in armed groups (UNHCR, 2018). Those elements make children vulnerable and easy targets for armed groups' recruitment as ISIS.

Over the last three decades, studies had well documented the child soldiers' recruitment process 
116 (Betancourt et al., 2013; Daxhelet \& Brunet, 2013; Jézéquel, 2006). Child soldiers are people under the age of 18 who are associated with military organizations. Children may be trained and used for combat, assigned to support roles such as porters or messengers, or used for tactical advantage as human shields or for political gain in propaganda (Daxhelet \& Brunet, 2013; Jeannet \& Mermet, 1998). Children are easy targets for military recruitment due to their greater susceptibility to influence compared to adults (Daxhelet \& Brunet, 2013; Le Quellec Cottier, 2012). Some are recruited by force while others choose to join up, often to escape poverty or because they expect military life to offer a rite of passage to maturity (Arzoumanian \& Pizzutelli, 2003). Child recruits who survive armed conflict frequently suffer of mental illness, poor literacy and numeracy, and behavioural problems such as heightened aggression, leading to a high risk of poverty and unemployment in adulthood (Betancourt et al., 2013; Mubiri-Pondard, 2008). Complementary, research has also found that the enlistment of adolescent children, even when they are not sent to war, is accompanied by a higher risk of attempted suicide (Ursano et al., 2016) stress-related mental disorders (Goodwin et al., 2015), alcohol abuse (Head et al., 2016) and violent behaviour (Bouffard, 2005; MacManus et al., 2013; Merrill, Crouch, Thomsen, Guimond, \& Milner, 2005).

In 2015, in Iraq and Syria, about 30000 armed individuals, originating from more than 100 countries were fighting under ISIS flag (Xingang, Wentao, \& Yulong, 2017), including children. In those regions of the Middle East, the use of younger children in armed conflict has increased in recent years as militant Islamist movements and the groups fighting them recruited children aged 16 and 17 in large numbers (United Nations Secretary-General, 2017). More especially, in Iraq, Human Rights Watch has documented the recruitment or use of children by Sunni and Shia Arab armed groups fighting in Iraq, including militias in the battle to retake Mosul. Armed groups in Iraq affiliated to the Kurdistan Workers' Party have recruited boys and girls in December 2015. About 29 cases have been documented in northern Iraq in which Kurdish and Yezidi children were recruited by two armed groups, the People's Defense Forces (Hêzên Parastina Gel, or HPG) and the Shingal Resistance Units (Yekîneyên Berxwedana Şingal, or YBŞ). The same tendency is happening in Syria since 2014, in which army groups have been recruited children as young as seven years old. More than half of the children recruited in cases verified by UNICEF in 2015 were under 15. Children have been filmed executing prisoners in grisly propaganda videos by the Islamic State group. In 2015 the UN said: "A total of 362 cases of recruitment and use of children were verified and attributed to ISIL (274), the Free Syrian Army and affiliated groups (62), Liwa' al-Tawhid (11), popular committees (5), Kurdish People's Protection Units (4), Ahrar al-Sham (3), the Nusrah Front (2) and the Army of Islam (1). Of the verified cases, 56\% involved children under 15 years 
of age, a significant increase compared to 2014." Knowing the objective of ISIS to restore the Islamic territory of the Caliphate Empire, as it existed in the medieval period, by using military forces to tear apart the Middle East and retrieve lands in Europe, Asia and Africa (Xingang et al., 2017), one may argue that all those elements put together let us think that ISIS potentially used its Physical Education under its education system to recruit and train future soldiers.

\section{Context: how ISIS took root in Iraq and Syria}

The Islamic State is a Sunni jihadist organization founded in 2006 as the Islamic State in Iraq. It is an armed group that opposes the power of Baghdad. In June 2014, after a series of military successes, ISIS seized Mosul, the country's second-largest city, and its leader, Abu Bakr al-Baghdadi, proclaimed himself "Caliph," successor to prophet Mohammed, and obtained the allegiance of several terrorist groups in the Middle East, Africa and the Caucasus. The armed conflict then spread to Syria, leading to a new exodus of people.

ISIS was born during the Iraqi civil war that began under the American occupation between 2003 and 2011. By 2004, in Sunni-majority regions of Iraq, a decentralized terrorist group led by Jordanian Abu Musab al-Zarqawi had begun to take shape. It was called Jama'at al-Tawhid wal-jihad [Oneness and Jihad], though it quickly came to be known as Al-Qaeda in Iraq. The organization's power peaked between 2004 and 2006. When the group's chief, Zarqawi, died in June 2006 during a raid by the U.S., jihadist leaders decided to join forces under a single name and chose to call their new group Islamic State in Iraq. In contrast to Al-Qaeda's idea of "Defensive Jihad," the Islamic State's Salafist vision is directed towards an "Offensive Jihad" (Xingang et al., 2017). To implement their vision, the jihadist leaders elected an Iraqi known as Abu Omar al-Baghdadi, who would be killed four years later, in 2010, just before American troops left Iraq. He was succeeded by another Iraqi, Abu Bakr al-Baghdadi, who soon bestowed upon the group an entirely different mission. Note that the leader of ISIS, Abu Bakr al-Baghdadi was killed in northwest Syria on Saturday, October 26, 2019, after being targeted by U.S. forces during an American commando raid. Since then, Abu Ibrahim al-Hashimi al-Qurashi has become the leader of ISIS.

\section{ISIS education system}

ISIS took hold in Syria and Iraq between 2014 and 2017 and its domination was followed by an elaborate educational system. The terrorist organization's "state program" is a unique case in recent history. Indeed, not only did it overturn the existing formal education system in Syria and Iraq, resulting in a hiatus in the schooling 
176 of children and teens, the organization went a step further by creating its own alternative educational system in its stronghold regions. More than 30 textbooks are forming a singular corpus of study never seen before and became the central element in the "jihadist resistance" against American occupation and the new Shia government installed by the Americans in Iraq (Guidère, 2017).

Several studies were conducted on this series of educational materials to better understand how ISIS had implemented its education system. More specifically, a first study focused on the integration of religious elements in the corpus of texts (Arvisais \& Guidère, 2020b). Another study presented the educational intentions targeted by ISIS through its textbooks (Arvisais, Bruyère, Chamsine, Mahhoua, \& Guidère, Submitted), while another one focused on how ISIS established its curriculum in the context (Arvisais \& Guidère, 2020a), and finally, the analysis of science textbooks also revealed an absolutist/theocratic ideological program that promotes a very inadequate concept of scientific activity and content (Potvin et al., 2019). However, the physical education curriculum recovered was not yet analyzed. Considering the context and objectives of the ISIS'S armed domination in the region, it seems relevant to analyze the physical education curriculum to better understand how the group attempted to use the discipline of the bodies to serve its interests.

\section{Objectives of the study}

This paper aims to describe and analyze the physical education curriculum implemented by ISIS in primary schools. Pedagogical and didactic perspectives (Lahire, 2007; Lahire \&Johsua, 1999) were used to help us understand the physical education teaching system in the context of ISIS, attempting to answer fundamental questions such as: what is being taught? In what ways? What are the relationships between school goals and practices and the real goals of ISIS group?

Consequently, the research question focused on describing the document (calligraphy, didactic, pedagogy aspects among others) and analyzing the general scientific quality of the curriculum of physical education that was addressed to the instructor in charge of the education of children. This study aims to:

1. Describe and analyse context and philosophy of the manual;

2. Describe and analyse content of the manual;

3. Propose recommendations for the humanitarian workers on the field. 


\section{Methods}

\section{Research design}

We conduct an explorative case study of the physical education curriculum implemented by ISIS for the primary school level. Exploratory research was chosen to determine research priorities, collecting data and focusing in on certain subjects, which may be difficult to take note of without prior exploratory research. Exploratory research allows the researcher to be creative in order to gain the most amount of insight on a subject (Creswell, 2014).

Complementarily, a case study methodology was applied for this research as case studies are highly suitable for exploring complex social, cultural, historical, managerial, and procedural phenomena when the situation includes many interesting variables, multiple sources of evidence, and broad theoretical propositions that guide the collection and analysis of data (Yin, 2014). The analysis of this special temporal curriculum is unique and has never been done before. Yin's three prerequisites, that justify using a case study method, are present in this project, notably that: a) the main research questions are either how or why; b) there is little or no control over behavioural events; and c) the focus of study is a contemporary phenomenon. This study remains descriptive, exploratory research and, as such, will focus on describing, in detail, the data collated from the document analyzed in relation with its context in which the curriculum has been implemented.

\section{Document Analyzed}

Our research team got access to various curriculum and education documents written, published and distributed by ISIS in northern Iraq between 2014 and 2017 (Arvisais \& Guidère, 2020a). All the material was posted online by ISIS itself and printed copies were also found in a number of schools around Kirkuk after its liberation. The corpus of documents forms a set of teaching materials that can be divided into two categories: subjects of a purely religious nature (textbooks on Doctrine, the Qur'an, Tradition, the Life of the Prophet, and Islamic Education) and traditional subjects (textbooks on science, mathematics, history, geography, physics, etc.). The document analyzed in this study correspond to the second category (traditional subjects) for the five years of primary school as proposed by the reform of the school pathway by ISIS.

This research focuses on the physical education curriculum implemented by ISIS. At this time, attempts to retrieve and analyze the other parts of the physical education program were unsuccessful. The manual was 26 pages long and composed of three sections. On the front page is a large image (Figure 7) with dark colors, 
mentioning, "teacher's manual," "physical training" for the "first level at the primary school," for the "first semester." In the first section, page 3 of the manual is a general introduction used in every ISIS curriculum documents that pays tribute to the God/Allah and the prophet. It explains the reasons and the context for the implementation of this curriculum by ISIS. Islam religion plays an important part at the beginning of this text. Also, page 4 is an introduction to the importance of a good physical condition for practising the religion and being a good Muslim. In the second section, the manual begins with a warm-up and stretching routines, which is repeated for each lesson, then17 lessons are followed lasting each for about 45 minutes. The last page of the manual is dedicated once again to a tribute to the prophet. The manuscript begins (p. 2) and ends (p. 26) with the Basmala in two different styles of Arabic calligraphy (circular and rectilinear) to give a religious connotation to the document (in order to receive blessing from God). Because only four authors were Arabic speakers in the present study, the manual was translated ${ }^{1}$ from Arab into French for conducting data analyses. Then, to make it as accessible as possible, the manuscript was written in English.

\section{Data Analysis}

Due to the special context, we conducted a qualitative data analysis, which was built using a step by step descriptive process. More specifically, we used an inductive analysis of the PE manual (form and content) throughout three dimensions. First, we analyzed the manual's philosophy in order to connect the main objectives with the context of implementation. Second, we conducted calligraphy and semiotic analysis using the concepts of denotation and connotation (F. Saint-Martin, 2011; Saouter, 2000) to better understand Arabic illustrations and pictures used in the manual. Third, we performed a content analysis of the manual's full textbook with pedagogical, didactical, learning and assessment perspectives.

\section{Philosophy and context of the manual}

In order to realize the analysis of the philosophy of the PE manual, we conducted a documentary analysis, by trying to connect and understand the document with the context of its implementation. Therefore, we took into consideration a) the scientific literature available in Arabic, French and English on this topic, which included previous studies on this corpus of ISIS educational materials, b) the types of calligraphies used in the

\footnotetext{
${ }^{1}$ Translation process was made by two different Arabic-French speakers, revealed modulations, and rearrangements in-between the two versions. Then, the manuscript was written in English and others arrangements were made (e.g., in French "nombre" and "numéro" became only "number" in English).
} 
manual and connected to this special context and c) semiology analysis with denoted and connoted principles. We performed a descriptive and inductive qualitative analysis with back and forth between manual, literature and analysis from calligraphy and semiotics.

\section{Meanings of the illustrations}

Calligraphy analysis

The manual uses many different Arabic calligraphies, so we decided to take a close look at the meaning of calligraphies (forms and meanings) that have been chosen by ISIS. To do so, we applied the steps of calligraphy analysis recommended by Bataineh, Sheikh Abdullah and Omar (2011) to the inscriptions inside the PE manual and also applied the semiology or the semiotic method (Magariños de Morentin, 2008). Even its decorative qualities, Calligraphy, from the Greek words kallos (beauty) and graphos (writing), informs about the script used and provides an important information about the text and the shape and function of the object. Arabic Calligraphy appears on both religious and some secular objects such as every medium-architecture, paper, ceramics, carpets, glass, jewelry, woodcarving, etc.

\section{Semiotic analysis}

The manual presents 38 pictures from the image on the front page to the illustrations of exercises inside each lesson. Following the recommendations of Preston, Wright \& Young (1996), we used the semiotic analysis to generate understanding through visual images and texts that are integral elements within the PE manual. We used the concepts of denotation (D) and connotations (C) which refer to the relationship between a signifier and a signified (Friedman \& Smiraglia, 2013). The denotation means the primary, the main, obvious or literal meaning of a sign. While connotations means other meanings, ideas or feelings that go along with the sign, it depends on the audience. According to Saouter (2000), visual languages helps users perceive, interpret and comprehend visible signs. For Mingers and Willcocks (2017), semiotics is a powerful tool to reveal the underlying meaning (including all cultural artifacts) of signs and symbols in the form of text, calligraphy, illustrations and pictures. In this study, we isolated each picture (Appendix A) and asked three authors of the research team to describe the pictures (denoted, Studium), and then explain the meaning under the picture (connoted, Punctum). Profiles of the coders were different in order to enlarge understanding: TG is from a North American culture and a native French speaker, LD is from a European culture and a native French speaker, GT is from a North African culture and is both a French and Arabic native speaker. All denoted and connoted contents were 
discussed through three meetings between coders and only some pictures were selected to illustrate our findings with consensus.

\section{Curriculum Content}

First, the content analysis was carried out using the text of the manual. We grouped the textbook content by using the SOEA (Subject-Object-Environment-Agent) model (Legendre, 2005) into several fundamental thematic in education such as Subject, Object, Environment, Agent, and their corresponding relations: pedagogy (subject-agent), didactics (object-agent), learning (object-subject) or assessment (Figure 1). We also used Bloom's Taxonomy (Forehand, 2010) to code the intentions and objectives of the lessons. The content was grouped into five categories: general introduction, manual introduction, material, game, content of lessons, and objectives. A word cloud was generated for each category using NVivo12 software. Similar singular-plural terms were grouped, with or without capitalization. We eliminated all three letters, connection words and articles. The format, color, font and orientation of the words in the cloud were not manipulated by the researchers and were generated automatically by the software. To analyze the word clouds, a semiotic analysis focusing on the denoted and the connoted (F. Saint-Martin, 2011; Saouter, 2000) was performed by the three coders. This was accompanied by a frequency analysis inspired by lexicometric analysis (Magariños de Morentin, 2008) in order to analyze the occurrences of the words in the texts translated into French from the Arabic version. This allowed to give more meaning to the text, to better understand it and to ease the interpretation of the different keywords highlighted by Nvivo12. The word clouds allowed us to visually represent the preponderance of certain words in the texts on the different pages of the manual. 


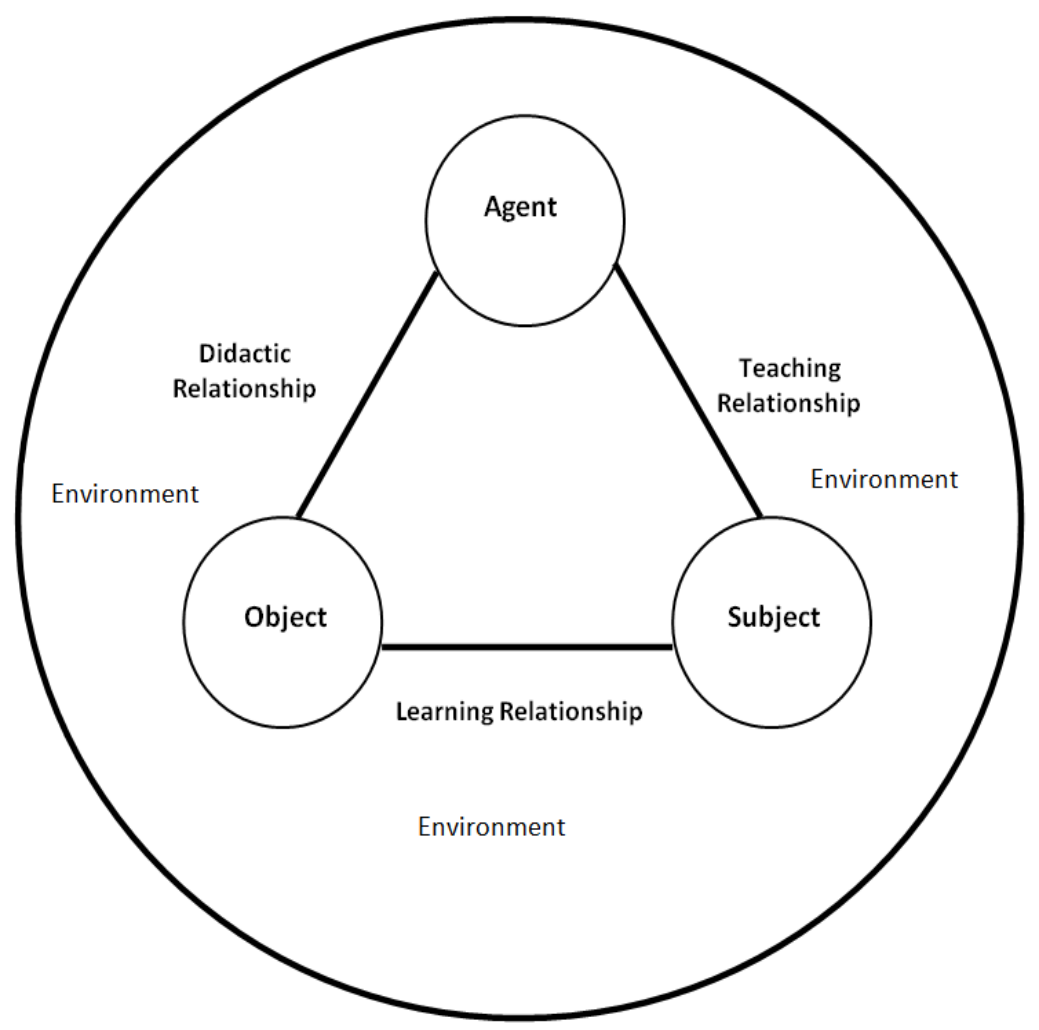

Figure 1. SOEA model (Legendre, 2005)

\section{Results}

\section{Philosophy and context of the PE manual}

Findings regarding the philosophy of the PE manual can be summarized into four points: a) form and content of the manual, b) manipulation of religion to serve the interests of the group, c) physical preparation of the future soldier, and d) vision of child development.

\section{a) About the manual (form and content)}

This short document (26p.) is especially designed for the use of the instructor or, so called, teacher (Agent) in charge of education, in contrast to the other curriculum documents made directly for students (Arvisais \& Guidère, 2020a). Thus, following the title of the manual, it focuses more on physical fitness preparation or training, than a physical education and sports, as announced, or even health curriculum. In addition, this manual clearly seeks to convey the values and ideas of ISIS, as it includes illustrations of ISIS in several places (p. 1, 4-7, 14) as well as a hymn to the glory of the group's leader the Baghdadi (p. 14). However, 
327 it is interesting to note that this book is the least religious document in the corpus compared to the contents of the other manuals, with less religious occurrences (Arvisais \& Guidère, 2020a). Analysis also reveals the poor quality of the Arabic writing. Several mistakes were identified in the textbook. Many illustrations used were not relevant to the content of the activities and were not helping to better understand the content or the intention of the curriculum. Finally, it was announced that the document was created using scientific and pedagogical references, but no mentions were available.

\section{b) Manipulating religion}

The reading and analysis of the manual reveals that the ISIS group relies on the Islamic religion to serve its interests and by manipulating its contents. The Islamic religion is therefore used but above all transformed to hide the real purpose of the manual, which seems to be to recruit new members of the ISIS group. Hidden behind the Islamic religion and numerous references to the God Allah (e.g., general introduction, p. 2), the emphasis is put on the leader of the group (Baghdadi) as soon as the opportunity arises. This seems to be a subtle adaptation of the Islamic religion to serve the interests of their particular group, considered to be the best.

\section{c) Physical preparation of the future soldier}

The analysis of the manual reveals that the ISIS group does not perceive the discipline of physical education as envisaged globally by UNESCO (2015). The main objective seems to be the preparation of a future soldier for combat or war by improving his general physical condition (title of the manual). There is therefore a strong emphasis on physical fitness to train the soldier to be ready to go into battle (Object). There also seems to be a focus on the rapid integration of civilians (children) into the army to fight enemies quickly. In many ways, the manual refers to organization, discipline, order, the non-commissioned soldier and good behaviour in line with its purposes (Didactics).

\section{d) Vision of child development}

Interestingly, there is no mention of student (Subject) characteristics (e.g., gender, age, needs) in the manual. For example, it is not clear whether the manual is equally applicable to girls and boys, what the age of the children in primary school is and what the learning expectations are for them. However, several avenues allow us to identify a certain vision of child development. First, we noted that repetition is essential since each 
lesson must be repeated three times according to the instructions in the manual. The warm-up and cool-down routines are repeated in each lesson, but with no connection to the rest of the lesson content while it should be the case. As well, six objectives out of 17 are formulated as "the student must recall," meaning first step of Bloom's Taxonomy associated with an order. Second, we believe that the group hopes to use this brainwashing strategy in the same way it did for child soldiers (Daxhelet \& Brunet, 2013). Lesson 7 is particularly interesting since the students have to line up to learn and sing a hymn to the Baghdadi leader. In this sense, students are made to believe that things are done in the name of religion, but this is a manipulation as mentioned above. Children are not developing critical thinking but are only repeating orders and rules.

\section{Meanings of the illustrations}

Calligraphy and illustrations analysis

In this section, in order to interpret the underlying meanings of calligraphy and illustrations presented in this manual, we use a semiotics approach (using the concepts of denotation [D] and connotation [C]). Hence, we selected 7 illustrations and calligraphy style from a list of 70 elements (see Appendix A). The choices of selecting these 7 elements, for this paper, were based on the criterion of significance and its representative in this study.

(D) First, we selected one style of the calligraphy text of "la Basmala" ("In the name of God, the All-Merciful, the Most Merciful." Figures 2 and 3 presented over 2 pages (circle calligraphy style) of this Arabic manual. It is important to remember that like Chinese Civilization, Islamic Civilization reflected in Writing. In the graphical field of calligraphy, the sign of the same type or style, Islamic in the case pursued here, differs between them. The tracings do not have the same articulation or the same cursivity ever.

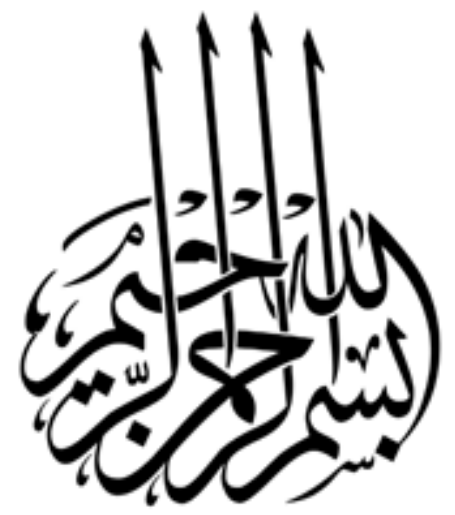




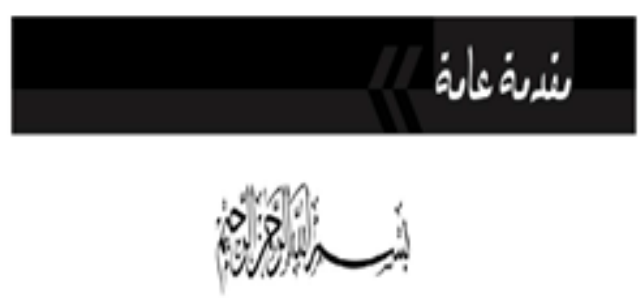

Figure 3. Calligraphies inside the PE Manual

(C) The basmala (Figure 2) is used at the beginning of each of the suras of the Qur'an, with the exception of the 9th Sura al-Tawba. This formula must be pronounced and put at the beginning of everything done by a Muslim in order to gain the "Baraka" (The Blessing) of Allah. Its presentation in Arabic calligraphy ("beautiful" cursive writing, the Naskhi) in a circular form (symbol of perfection) may refer to "the image of the immanent divine Reality that resides in everything." The basmala is in a rectilinear layout (simple and linear calligraphic style; p. 3). It's mentioned in the beginning of the general introduction used generally in every ISIS curriculum documents, which pays tribute to the God Allah and the prophet Mohammed.

(D) Second, we selected one style of illustrations presented over 4 consecutive pages (4-5-6-7) of this manual (Figures 4 and 5). On page 4 of the Arabic manual, there is an introduction draft in a different box with colourful ornaments and flower decorations (in 6 heart petals) on the left side; and the black flag of ISIS on the right side. The whole is followed by the basmala ("In the name of God, the All-Merciful, the Most Merciful") with simple printed letters and not a particular style of Arabic calligraphy. On page 5 (Figure 5), the warm-up section is found in a box similar to the one in the introduction; that is, with colourful ornaments and flower decorations on the left side; and the ISIS flag on the right side. A main addition between the two floral decorations (of different sizes) is a silhouette of a soldier (shoes, water bottle, helmet) in a rope drill. Note that this same style used on page 5 is repeated in the following pages: 6 and 7 which deal respectively with the continuation of the warm-up and stretching exercises. 


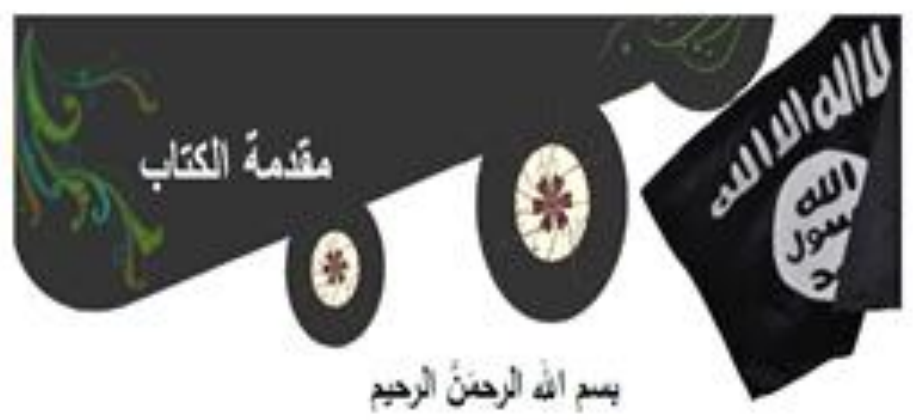

Figure 4. Illustrations inside the physical education manual

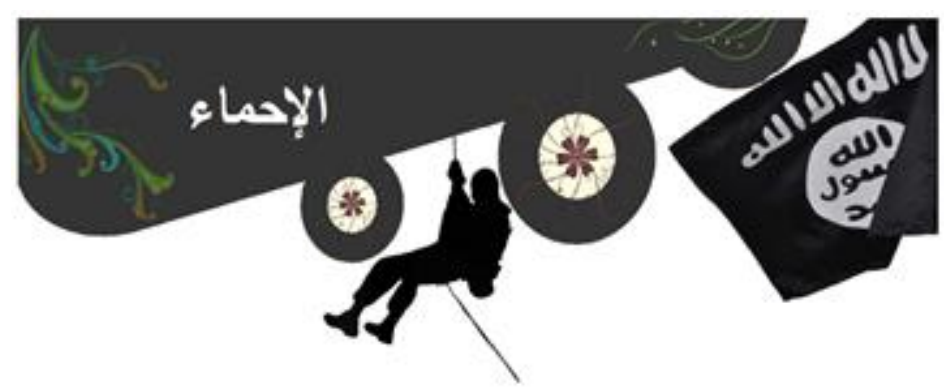

Figure 5. Illustrations inside the physical education manual

(C) The presence of the ISIS flag in the book's introduction allows us to clearly distinguish the relation between the manual and this group. The manual is made by and for the members of ISIS. The ISIS flag: "embodies the Islamic faith statement: 'I testify that there is no god but God, and that Muhammad is God's envoy/messenger.' His whole being appears thus impregnated and transformed by the truth." The presence of the basmala confirms the origin of the production of the manual and the Muslim custom of starting everything with the basmala. The religious imprint is strong in this manual, which is supposed to be academic. In some states, one would have to deal with public (state) education and private education (religious borrowing). There is no choice. Religion is imposed in the education offered by ISIS. Same as before with the addition of a silhouette of a soldier rappelling down to suggest an armed force that is consistent with the military character of the manual noted in several other places in the manual, but not consistent with the usual images of ISIS. The association on the same page of the ISIS flag and a military member sets the tone for the orientation of that state and its ways of doing things. It is far from the intent of physical preparation to ensure good health and well-being. This is military preparation. Presence of elements of nature in ornaments and decorations using 
different colors: Green: Nature; hope, luck, stability and concentration; Turquoise: declination of blue; colour of the sea and sky; good waves and wisdom; Brown: noble; serenity; gentle, reassuring and almost maternal. Bordeaux red: energy, love, determination, joy and prowess. Bordeaux red flower with six heart-shaped petals to express affection and love. Usually the odd number is preferred in Islam. It is widely used in jewellery and decorations, but has five petals.

(D) Third, we selected one illustration (Figure 6) used/repeated or reproduced in all the pages of the different lessons in the manual (i.e. from page 8 to page 24; it is just the number of the lesson that changes). On page 8 of the Arabic textbook, the title of the lesson is mentioned with letters printed in white in a slightly dark grey box with a decoration on the right side in the form of three regular, intersecting hexagons. The first one is light grey, where the word "State" is written in Arabic with a particular style of black Arabic calligraphy. The second box is purple or violet and bears the word "of the Califat" in Arabic calligraphy (white colour) and on the third black hexagon is written "Islamic."

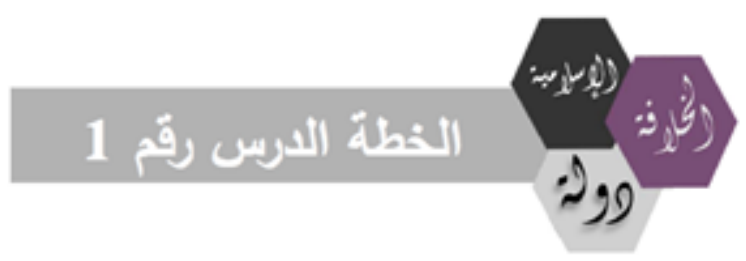

Figure 6. Lesson calligraphy inside the PE Manual

(C) The presence of three hexes confirms the value of odd numbers in Islam. The hexagon can be found in nature (example beehive: it is through this association that the hexagon has become a symbol of work, rigour, organization, perseverance and collective effort); The hexagonal shape is used in the building trades and manual trades in general to symbolize the difficulty of the trades. Three hexagon (Violet, black and grey) are presented in this illustration: violet, the colour of royalty; Black: blackness, darkness and Grey: mixture between black and white, neutral colour, used to highlight other colours. A bland hue associated with sadness and loneliness. The title and number of the lesson is in white (purity and innocence). Here highlighted by the slightly dark grey.

Illustrations analysis

Front page 


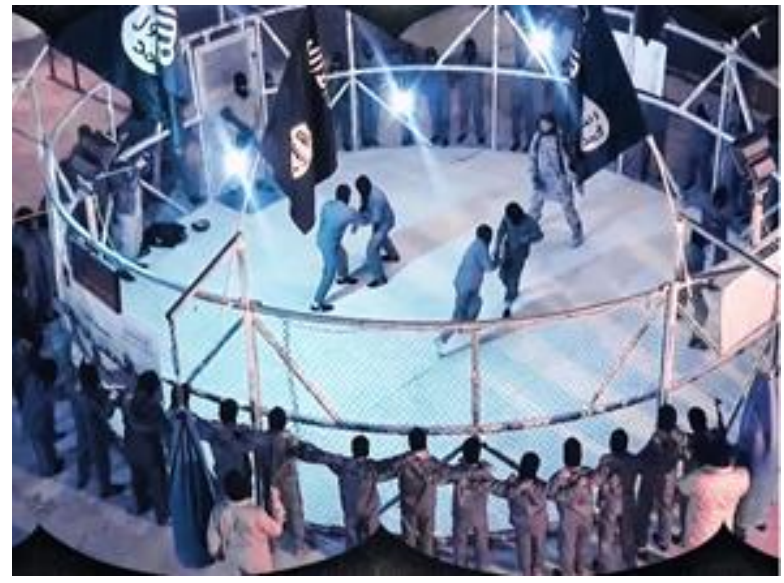

Figure 7. Front page of the PE manual

(D) Figure 7 is the cover image of the manual. This is an illustration/"showcase photo" for the manual with many elements. This is a photo of a combat arena (spectacular staging) enclosed by wire mesh and taken in medium shot/"landscape" format. This staging illustrates a kind of military training. From the outside going towards the inside of the arena, we observe different people who have to see with each other. On the first level, from the back, we see fighters or security guards (adults depending on their size) dressed in caramel-coloured military suits carrying weapons (Kalashnikov) doubling their attention and serving to secure the scene and above all "to deepen the depth of field, making it possible to give the scene more reality. The "control, discipline, authority": control, discipline, authority; surrounding other slightly young fighters dressed in military jumpsuits (caper green/or military green; photographed from behind with their eyes focused on the arena) and glued together making a belt of the public around the arena (solidarity and fraternity between the fighters); but also waiting to fight in turn afterwards. The staging of the action of a framed military training of the ISIS opens with three bare-handed fights (duels) of young hooded men dressed in military green jumpsuits in combat action under the instruction of a referee who is faceless and (but his features are erased) wearing a black scarf on his head and hiding his neck dressed in a military suit. We also see an adult security guard like those outside (surrounding the arena) carrying a weapon (kalashnikov) and a person dressed in black whose head and face cannot be seen (cameraman) is filming or photographing the fight. At the top of the arena hang three ISIS flags, light projectors, a poster attached to the arena fence, and heavy bags on the sides to hold the fence.

(C) This picture reveals the ISIS curriculum, values and ideas on many points. Through its prevalent frontal perspective, the illustration or showcase image on the cover of the physical preparation manual presents several visual signifiers, a hybrid of the visual and a verbal of concrete military training scenario 
photographed with additional/enhancing lighting at night: The lighting conditions of the scene (the L.E.D. spotlights) produced this decorative filler imprint on the cover of the manual. The overall plan is wide enough to see several characters and elements of the scene, including duel fights. This means that the photograph has a great deal of truth in it. The presence of several people in action in the photographed scene makes their relationships interpreted. Consequently, two questions then arise: a) what was chosen to be shown? b) What was chosen not to be shown?

They have been chosen to show an arena surrounded by wire fencing and guarded by a soldier reminds us of the Roman arena where gladiators and animals fought to death. In a more contemporary history, this image refers to the Mixed Martial Arts (MMA) fights: fights involving a combination of martial arts, which at its origins had few, if any rules (cfr Vale Tudo). Note also that for a training fight, it is surprising that the fighters wear shoes. There is a public distance to the stage that does not require the participation of spectators. The young hooded men dressed in military green jumpsuits wearing a balaclava may be intended to hide the faces of the fighting soldiers; it may also support the idea of dehumanization and depersonalization of the opponent. There is also an imposed ambivalence: on one side we are shown a brotherhood, a group of solidarity, arm in arm, forming a solid circle. On the other side, social bonds are cut by hiding, by a hood, the face of the brother who then becomes the adversary. Fighting is done under the instruction of an open-faced referee (but his features are erased) with a black scarf on his head and hiding his neck dressed in a military suit. The whole thing is filmed by a person who is not wearing a military uniform/suit, looking for cinematographic/Hollywood effect.

They have chosen not to show the faces of the fighters and security guards: not recognizing them and emphasizing the idea of dehumanization and depersonalization of the opponent. This is a spectacular and high-profile military training for ISIS terrorist militias as shown by the ISIS flags around the arena. This group has the habit of filming their battle scenes to talk better about themselves and scare others. The end of the physical preparation manual will be used for this kind of scene in action in combat.

In this section, we selected two illustrations (Figures 8 and 9) repeated over different pages of this manual.

(D) On page 8 of the Arabic textbook, under the box of the main part of lesson 1, there is the Figure 8 repeated/reproduced on page 9 as well. It shows several dark brown oval shapes with small grey circular shapes centred on them. The small format is aligned and the large format is in front. Note that these small shapes are 
reproduced in other diagrams on the following pages of the manual: 10, 11 and 14 .

\section{الجزء الرئيس 30 دقيقة}

Figure 8. Illustration of lesson 1 of the PE manual

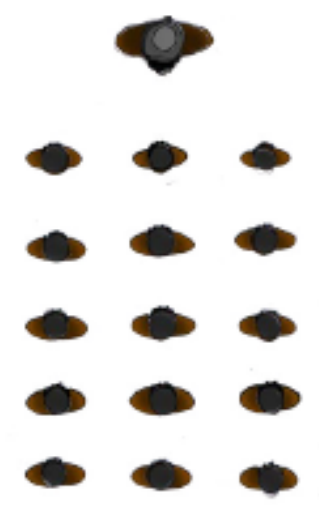

Figure 9. Illustration of lesson 7 of the PE manual

(C) This image appears to be a representation of a group seen from above (photo taken with a drone) with an instructor-teacher-monitor in front facing them, leading and supervising students (younger than him) who are placed in order and in line. The students face the instructor and stand up straight (reference to the military). The elements forming the group are smaller in size than the element facing them. This would be a representation of a group of students facing a teacher. The arrangement of the group is very structured. Each individual is aligned with the others. Very orderly representation of a group. This arrangement connotes a military and non-academic rank formation. An arrangement in a school setting would rather be represented as a semicircle of students facing a teacher. This is an illustration that is not pedagogical, but rather military.

(D) On page 11 of the Arabic textbook, under the box of the main part of lesson number 4, and parallel to the instructions of "some Swedish exercises like jumping" we find Figure 10. It is a figurine of a boy (dressed in a suit [a sort of long burgundy tunic + wide brown trousers] and small black slippers; the features of the face are erased; the arms stretched out sideways and his legs bent) near or above a black object and two arrows coming out on both sides in purple 


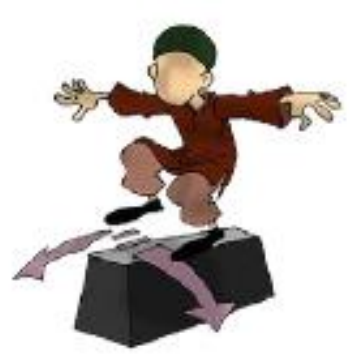

Figure 10. Illustration of lesson 4 of the PE manual

(C) A child dressed in an outfit (probably traditional local clothing or a reference to the ISIS dress identity) that is not suitable or recommended for physical activity and even military preparation (strongly emphasized from the manual cover page) in dark colours (no facial features and wearing a black headdress) who makes a jumping movement over an obstacle, but the movement is odd because the most natural movement would be to jump over the obstacle from the front and not from the side. Exercise and illustration not clear. Note that the Muslim religion forbids to represent the face of God or the face of the Prophet, but not of other people. Figures with clothes are more appropriate for boys and not girls in the context of ISIS. The colours of the clothing vary in the illustrations. Therefore, we are dealing with a uniform in terms of style, but not in terms of colour. The illustration is meant to serve a useful function for the teacher: it describes the exercise proposed in the lesson. The object depicted is described in the text as "an object about $50 \mathrm{~cm}$ high." In this lesson, no material is recommended outside a "suitable yard." The feasibility of this lesson should be questioned, as an object about $50 \mathrm{~cm}$ high is not likely to be easily found.

\section{Curriculum Content}

Findings about the curriculum content are presented thru six word clouds, generated by the software Nvivo12. The first two word clouds correspond to the manual general introduction and the manual introduction. The next four word clouds correspond to the four main section of the 17 lessons and are presented in the same order as they appear in the manual, namely, the objective, the equipment, the general content of the lessons and the game. Whilst analyzing the curriculum content, one lesson, number 7, appeared to the research team as very different from all the others. A comparison of this specific lesson is made with a more 
representative lesson found in the manual, namely, lesson 6. Each section presents the denoted part followed by the connoted part of each word cloud.

\section{Manual sections}

General introduction

In page 3 of the Arabic manual translated into French, the general introduction occupies the entire page (Figure 11).

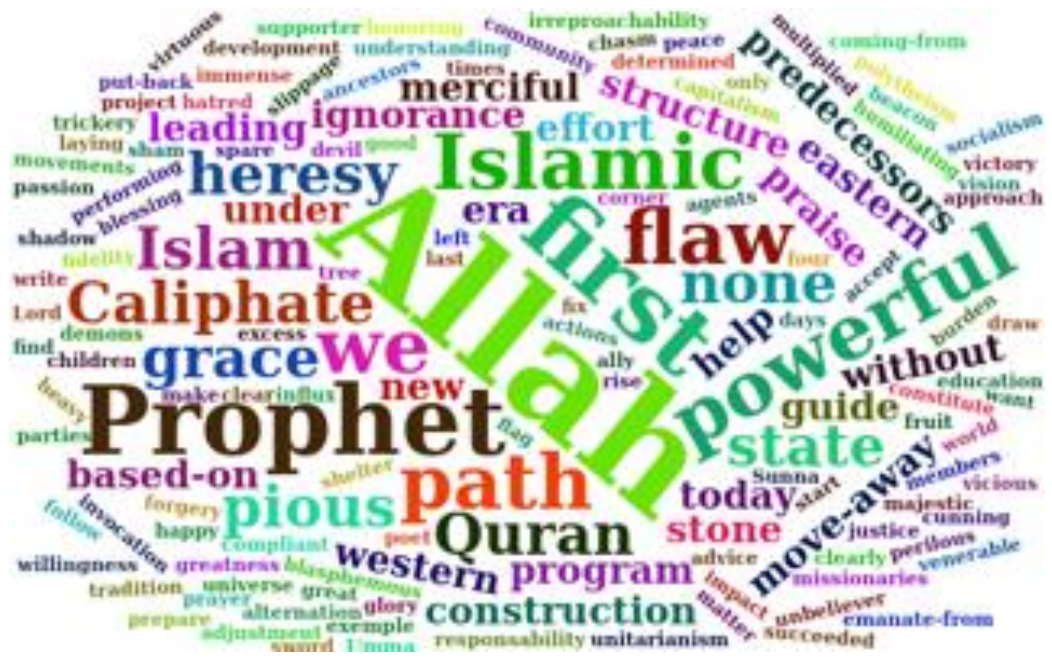

Figure 11. Words clouds about general introduction

(D) The text is written with an Arabic typography different from the style used in the rest of the textbook and takes the classical form of a speech that can be delivered orally. It begins with the Basmala: "In the name of Allah, Most Gracious, Most Merciful." The most used word is Allah (8). Many references are made to Allah: His grace (3), His help (2) and His blessing (1). The highlighted words are: first (5), prophet (5), Islamic (4), we (4), powerful (4). A second group of words, quoted three times, stand out: caliphate, Coran, fault, grace, heresy, Islam, the state, pious. In a third group of words, there are references to the enemy: cited twice: ignorance, western, eastern. Cited once: blasphemous, capitalism, devil, defect, demons, slip-ups, falsification, hatred, humiliating, imposture, irreproachable, justice, unbelievers, polytheism, cunning, socialism, trickery, vicious, victory, sword.

(C) The general introduction of the manual is written as a foreword/preamble and is quite unusual for a teaching manual. Indeed, we find the typical ISIS group discourse tinged with hatred, on a salient background 
of religion, as defined by the ISIS group: "Islamic education; a new curriculum." Religion is omnipresent to guide the education. Everything is done in the name of Allah, but with a "clear vision" (p. 3) that defines the identity and purpose of ISIS: "neither eastern nor western, but prophetic Coranic which distances itself from the passions, heresies and impostures emanating from the missionaries of Eastern socialism, Western capitalism or agents of vicious parties and movements around the world" (p. 3). This introduction presents as well a lexical field defining the ISIS group: State of the Caliphate or Caliphate Edifice. At the end of the general introduction, the efforts made to write this manual are acknowledged and an openness or predisposition to criticism, advice and modification from "any supporter (ally/friend)" is suggested. This last clarification therefore indicates that not all criticism is welcome despite a so-called openness.

Manual introduction

In page 4 of the Arabic manual and translated into French, the introduction occupies the whole page and is written with the printing letters and no special calligraphy (Figure 12).

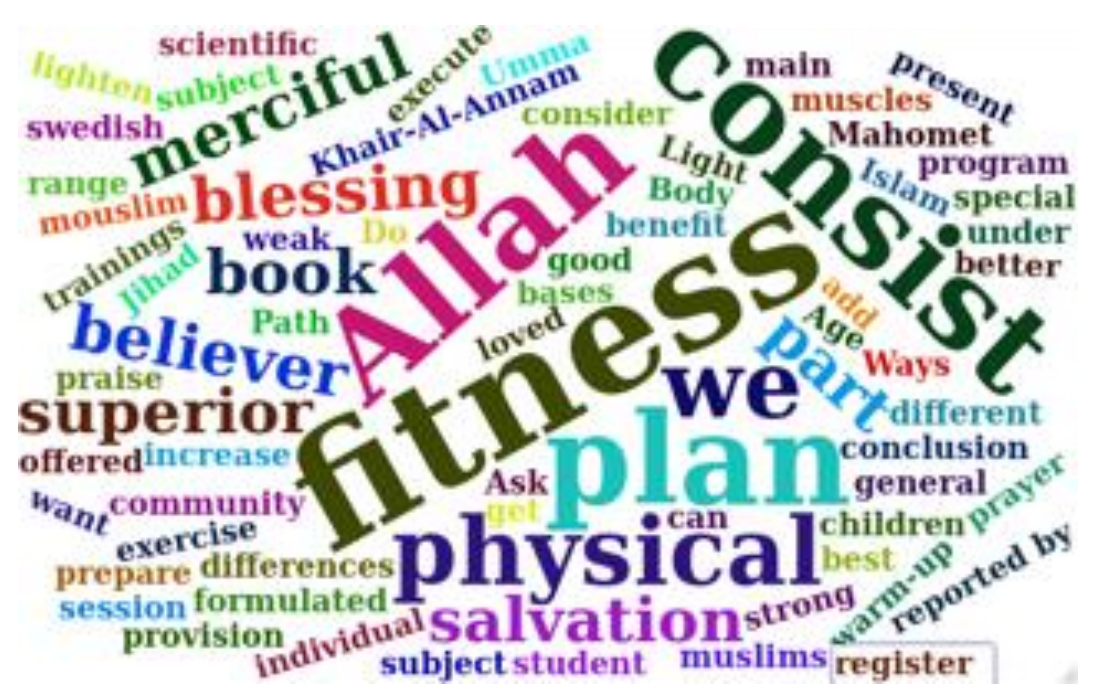

Figure 12. Words clouds about manual introduction

(D) The word "fitness" (cited 5 times) is predominant. "Fitness" is associated three times with the word "physical." Then, three groups of words emerge. A first group of words consists of the following words: Allah (4), plan (4), we (3) and physical (3). A second group of words consists of words quoted twice: blessing, believer, book, merciful, part, salvation, superior. This last word characterizes "physical fitness." A third group of words, 
quoted once, offers references such as Annam, children, training, weak, strong, Jihad, Khair, Islam, Umma, student, Mahomet, Mohammad, Muslim, program, pedagogical, scientific, Swedish, age, individual.

(C) This introduction is more specific to the contents of the manual: "a special program for fitness," for "a higher form." It presents the program, proposing lesson plans, promoting a single goal and intent of superior fitness. The text is presented as a religious document that integrates a fitness program. Indeed, this introduction presents the direct link woven by ISIS between physical fitness and religion, authenticating the words of the Prophet Muhammad. However, the statements quoted have not been made in the sense mentioned in this manual: strength and fitness were not mentioned by the Prophet (Al Otheemeen, 2020). There is therefore a diversion of meaning for the purposes of the manual, and ISIS more broadly. On the other hand, the ends of the training expectations are not clear. Who is trained? Why and to what ends? However, by referring to the cover page of the manual, the general introduction and the direct mention of the term "Jihad," the purpose of the text becomes clearer. These various indices imply a fitness training of a future fighter or soldier to fight the enemies of Islam, as defined by ISIS. Therefore, it is a matter of military physical preparation and not physical education.

In addition, several shortcomings are noted in this manual. Contrary to the words of the text, which claims to be scientifically and pedagogically based and to consider age and individual differences, none of this appears in the lesson plans. No bibliographic reference and no gradation of difficulty is proposed. There is no information on the students, which makes it impossible to take their needs into account. Finally, there is a certain contradiction in the content of the general introduction, which emphasizes "a clear vision, neither Eastern nor Western" (p. 3), and the introduction to the manual, which states that the program is based on Swedish exercises.

Equipment

From pages 8 to 24 of the manual, the 17 lessons plans are found. Each lesson begins with a list of equipment to be used in the lesson (Figure 13). 


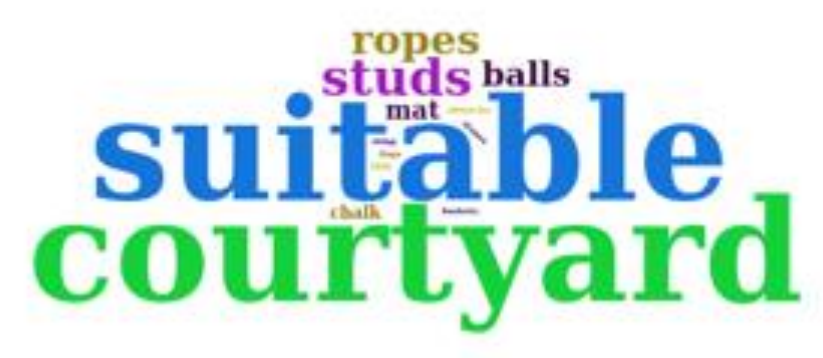

Figure 13. Words clouds about equipment

(D) In all 17 lessons, the word "courtyard" is found in the equipment list and always associated with the word "suitable"/proper, to form "suitable courtyard." A first group contains the most common words and includes blocks (6), ropes (5), balls (4). A second group of words includes mat (3), chalk (2), small (2). A third group of words mentioned once: two, flags, string, ISIS, obstacles, baskets, stones. Two words are associated in this last group: "ISIS flags." The material used is very rudimentary with ropes (p. 16), strings (p. 24), stones (p. 18), baskets (p. 13), balls (p. 13), chalk (p. 20) and El flags (p. 14). No information is mentioned on infrastructure other than the suitable court.

(C) From this list, we can understand that the equipment is quite rudimentary. Ten different types of equipment are listed for a complete physical fitness training textbook: blocks, ropes, balls, mats, chalk, flags, string, obstacles, baskets and stones. Apart from balls, the material proposed is more useful for the demarcation of the field, than for a potential manipulation of objects by the student or even for the development of his physical fitness. Most of the equipment is easily found. The reference to a "suitable courtyard" in every lesson rises questions. What is meant by "suitable?" Is it referring to training ground like the picture of the book cover or simply to a safe or protected location? On what criteria is it decided that the courtyard is "suitable?" The Cambridge dictionary defines suitable as "acceptable or right for someone or something." The use of the word "suitable" helps to keep the expected state of the infrastructure unclear, which therefore remains at the teacher's discretion. This suggests that these lessons are not given in schools designed for this purpose. Is this related to a context where access to quality infrastructure and resources is limited, such as remote areas or crisis or war contexts? Or with the geographical conditions of the region? Or the ISIS gathering place? 
Objectives and intentions

On each page, from page 8 to page 24 of the manual, there is a boxed text presenting the objective of each lesson (Figure 14).

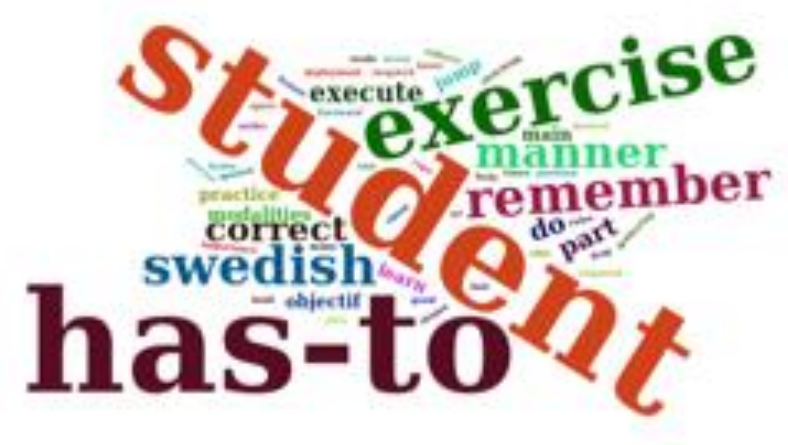

646

Figure 14. Words clouds about objectives

(D) The group of words that comes up most often is "the student must" (16 out of 17 objectives). This group of words is followed by an action verb: recall (6), execute (3), do (3), practice (2), run (1), squat/crouch (1). The next most used word is "exercise" (10). The word "Swedish" (6) is always associated with it, to form "The Swedish Exercise," listed in 6 objectives out of 17. A second group of words stands out: correct (4), manner (4), execute (3), do (3), part (3). The group of words "in a correct manner" is used 4 times out of 17 objectives. In a third group, particular words are mentioned once: deployment, hymn gathering.

(C) In the manual, no mention or distinction is made between general and specific objectives. The objectives are formulated as "the student must" + action verb. These verbs have been organized according to Bloom's taxonomy (Forehand, 2010). According to Bloom, objectives should cover different cognitive levels. These levels are ranked in ascending order of cognitive difficulty: knowledge, understanding, application, analysis, synthesis and evaluation. The verb "to recall" relates to the level of knowledge and is the most used of all. The verb "to do" relates to the level of understanding, and the verbs "to execute" and "to practice" relate to the level of application. Two objectives concern only the psychomotor domain (to run and to squat). The objectives are aimed at cognitive operations of low difficulty that do not require much autonomy from students. 
Also, the objectives are not SMART. As a matter of fact, the objectives are not clear as to the what, where, when and how (Specificity, e.g.: "as required"). The use of the word "correct" is unclear (Measurability) as there are no success or achievement criteria to define what is "correct" or not. The assessment seems to be left to the teacher without any other form of measurement. The objectives are not motivating, do not represent an ambitious and attainable challenge (Acceptability and Realism). Finally, the objectives are not defined temporally (Temporality). No distinction is made based on the age and the objectives are not evolutionary. There is no gradation in learning.

On the other hand, several words are taken from the military terminology. For example, lesson 2's objective uses the words: "deployment, gathering, precision." In lesson 2, it reads: "... so that the students learn the discipline." Discipline is omnipresent in the manual as the last sentence of each lesson exemplifies: "back in line regularly." Also, the objectives of lessons 5, 7 and 11 are not related to the main part but to the "game" part of the lesson. However, the games are presented as modular unlike the main parts. Logic would dictate that the objective should be directly related to the main game and not to the game. This structure is incoherent. In addition, the objective of Lesson 7 has nothing to do with physical preparation (see analysis L6 versus L7). Finally, the continued reference to Swedish, and therefore Western, exercises contradicts the desire, expressed in the introduction of the manual, to move away from the Eastern and Western world to be inspired only by Allah and Islam.

From page 8 to page 24 of the manual, the main part of the lesson occupies the centre of the page for each of the 17 lessons (Figure 15). The text is often accompanied by illustrations that may or may not be related to the content. 


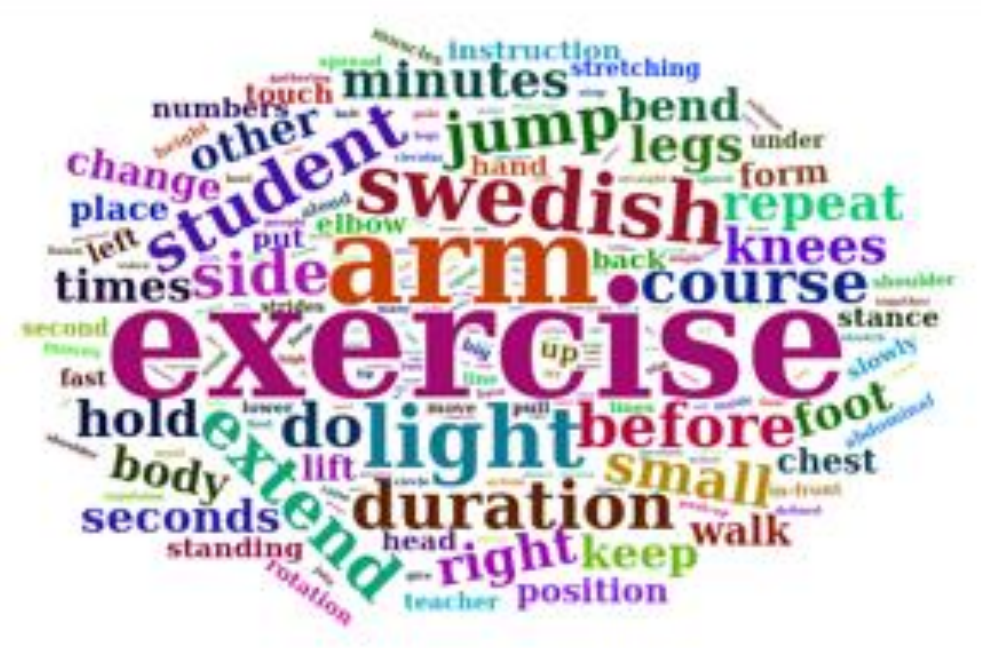

Figure 15. Words clouds about general contents of lessons

689

690

691

692

693

694

695

696

697

698

699

700

701

702

703

704

705

706

707

708

(D) The most used word is exercise [29] followed by "arm" [21]. The word group "Swedish exercise" comes up 15 times. A first group of words stands out: duration [12], student [12], forward [11], run [11], side [11], do [11], jump [11], small [10]. There are also many references to the body and its different parts: arms [21], knees [9], legs [9], body [8], foot [8], chest [6], elbow [5], hand [5], head [5], shoulder(s) [5], abdominal [3], muscles [3], ankle [1], hip [1], hamstrings [1], leg [1], calves [1]. Few active verbs are used in the text: do [11], repeat [9], stretch [9], hold [9], keep [8], change [7], walk [7], put [5], jump [4], lie down [3], spread [3], move [3], pull [3], try [3], drop [2], bend [2]. These verbs are sometimes conjugated with the infinitive form and other times with the imperative form. Finally, a few particular words are mentioned once: Amir, deployment, assembly, prince.

(C) As the title indicates, this manual is aimed at physical preparation and not physical education. A physical preparation often apprehends a military formation and an active participation in fights and wars. In the main part, the proposed exercises are individual. There is no cooperation or interaction between students [e.g., giving, catching, etc.]. Most of the exercises consist of body movements (e.g., Swedish exercises). There is no modern exercise such as throwing or catching objects. After the Swedish exercise [15 lessons out of 17], running is the most mentioned exercise [8/17], followed by jumping [6/17]. Exercises such as push-ups are offered when they are not suitable for primary school age children. Verbs are conjugated with the infinitive or the imperative form. Yet, this book is intended for the teacher. Then, why verbs are in the imperative form? Indeed, the instructions for the students are already prepared in the textbook and ready to be simply read by the teacher. Therefore, it seems like the teacher has little freedom to adapt knowledge and make it teachable. 
Games and activities

From page 8 to page 24 of the manual, each main part of the 17 lessons ends with a "little game" (Figure 16).

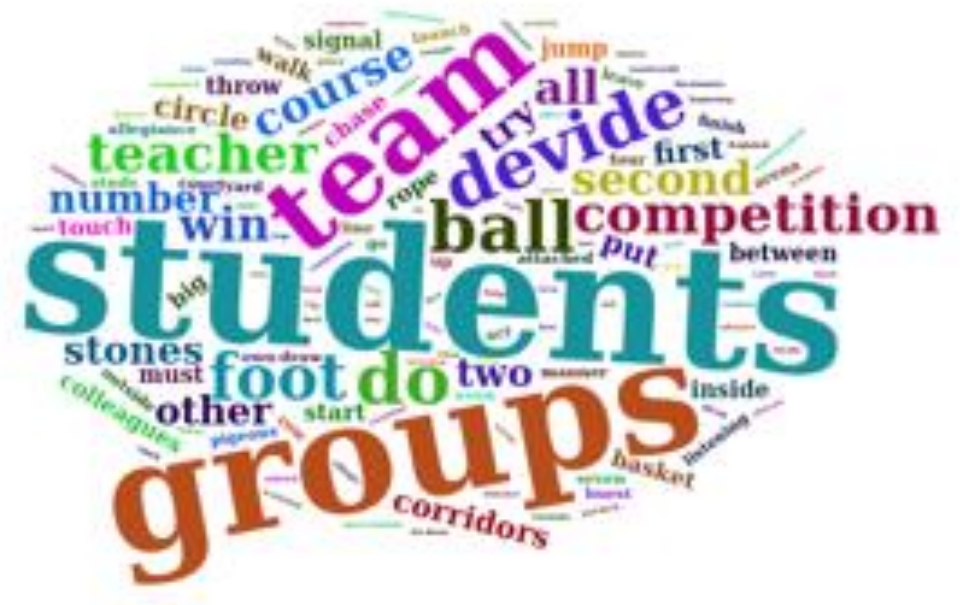

Figure 16. Words clouds about games

(D) The most used words are students [21], groups (20) and team (14). A second group of words consists of: teacher [7], competition [7], divide [9], ball [9], foot [8] win [6], stones [5], hunt [4]. A third group of words stands out. It contains specific references such as: colleagues [3] allegiance, Amir [1], Fatimide [1], Hachimiste [1], anthem [1], master [1], prince [1] Baghdadi [1].

(C) In the manual, the games are intended to put groups or teams in competition so that there is just one winner in the end. This competition principle appears explicitly in 14 lessons out of 17. In the other three lessons, the idea of competition is latent as there is division into groups and running among the students. There is no mention of cooperative games, interaction or cooperation among students for any purpose other than to win against others. Lessons 8 and 14 suggest the same game. Once again, some terms are not appropriate in a fitness manual [allegiance, Baghdadi) and refer directly to ISIS. The most notable example is the game in Lesson 7, which is an attempt at indoctrination and fidelity to the state. At the end of each set, the same note is mentioned: "Note: The game is an idea to support the teacher. The teacher can give the students more games." First, it is legitimate to ask, "who is this teacher?" Is he a military man or a physical education teacher? 
Second, in a textbook that is intended for the teacher, where instructions for students are written in imperative form and simply repeated, what is the actual limit of the flexibility given to the teacher?

Lesson 6 Versus Lesson 7

Finally, we did compare two lessons in terms of content. The following Figure 17 presents a comparison of word clouds from two lessons from the textbook, lesson 6 and lesson 7. Lesson 6 is typical and representative of the lessons proposed in the manual and has the following objective: "The student should remind the students of the importance of Swedish exercises for the lower part of the body." This objective is clearly aimed at physical preparation. Lesson 7 has a unique and very different objective from the other lessons: "The pupil shall learn the hymn mentioned below." Indeed, this objective is not aimed at physical fitness but rather a recitation of an allegiance hymn.
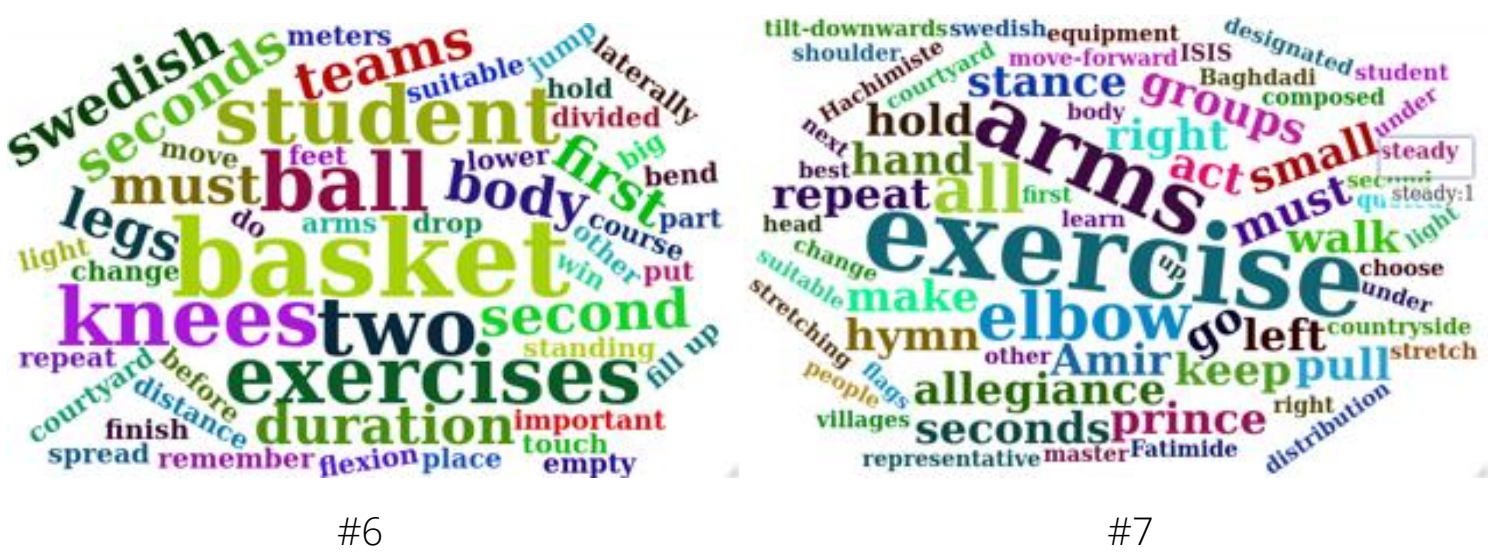

Figure 17. Comparison of lessons \#6 and \#7 words clouds

(D) In the lesson 6, three groups of words are identified. A first group consists of the most used words: baskets (4), balls (3), two (3), exercises (3), knees (3) and student (3). A second group of words, cited twice, stands out: body, second, must, duration, legs, first, seconds, Swedish, teams. A third group is composed with words that are used only once. The verb "must" is used twice. A group verbs, used once, consists of recall, spread, hold, do, lower, bend, touch, change, repeat, divide, put, move, finish, win. The required equipment comprises balls (3), baskets (4) and a courtyard (1).

(D) In lesson 7, three groups of words are identified. A first group consists of the most used words: exercise (5), arm (4), elbow (3), all (3). A second group of words, cited twice, stands out: act, go, amir, must, right, 
allegiance, do, keep, left, groups, hymn, hand, walk, small, posture, prince, repeat, seconds, hold, pull. A third group is composed with words that are used only once. In this group of 40 words, eight particular words stand out: Baghdadi, country, flags, fatimide, hachimiste, ISIS, master, villages. Several verbs are used twice: must, pull, hold, keep, repeat, walk, go, do. Other verbs are used once: learn, chose, change, stretch, bend, designate, move forward. The required equipment comprises flags (1) and a courtyard.

(C) The key words stemmed from the analysis of lesson 6 are consistent with words that would be found in a physical education lesson. The main part of the lesson consists, as in 15 out of 17 lessons, of making body movements, called "Swedish exercises." The exercises are individual, there is no interaction or cooperation between students, and the game part is a competition. The required equipment is rudimentary. On the other hand, the objective of Lesson 7 has nothing to do with physical preparation. The key words stemmed from the analysis of lesson 7 are indicative of its unspoken goal of indoctrinating and training the future ISIS soldiers. In this lesson, students do "a regular walk with the same organized rhythm," they stop and resume following the teacher's instructions whilst singing a hymn. This exercise strongly resembles a military walk or even, a parade in a dictatorial regime. As a matter of fact, the anthem pays tribute to the Baghdadi, head of the Islamic State. It sounds like a propaganda urging young people to swear allegiance to him. Contrary to the introduction which put Allah and the Prophet in the central position, there's a shift towards the head of state in this lesson. There is also a reference to the word "Amir" used to refer to the leader or commander. The group chooses its own "Amir." Once again, the military organization is suggested and supported by an illustration on the same page of the manual.

\section{SOEA Model}

Table 1. Synthesis of the SOEA for the Physical education curriculum of ISIS

\begin{tabular}{|l|l|l|}
\hline & Present & Missing \\
\hline Subject & - Illustration of kids, probably boys & $\begin{array}{l}\text { - Gender, age, size, weight, morphology, ability or } \\
\text { disability } \\
\text { - Needs of kids }\end{array}$ \\
\hline Object & $\begin{array}{l}\text { - The State } \\
\text { - Islamic religion revisited by ISIS } \\
\text { - Physical preparation/physical } \\
\end{array}$ & $\begin{array}{l}\text { - Child's development } \\
\text { - Child's physical and psychological well-being }\end{array}$ \\
\hline
\end{tabular}




\begin{tabular}{|c|c|c|}
\hline Environment & $\begin{array}{l}\text { - Suitable courtyard } \\
\text { - Rudimentary equipment } \\
\text {-Missing/inappropriate or unsuitable } \\
\text { equipment }\end{array}$ & $\begin{array}{l}\text { - Location and state of the infrastructure } \\
\text { - Criteria of a "suitable" courtyard } \\
\text { - Modern equipment } \\
\text { - Appropriate or suitable objects or equipment to han- } \\
\text { dle }\end{array}$ \\
\hline Agent & - Teacher & $\begin{array}{l}\text { - Information on who's the teacher/instructor } \\
\text {-Qualification or training of the teacher/instructor; } \\
\text {-Teacher education, experience and background }\end{array}$ \\
\hline Pedagogy & NA & Teaching and learning processes of physical activity \\
\hline Didactics & - Swedish gymnastic & $\begin{array}{l}\text { - Achievement criteria } \\
\text { - Success criteria }\end{array}$ \\
\hline $\begin{array}{l}\text { Learning and As- } \\
\text { sessment }\end{array}$ & $\begin{array}{l}\text { - The pupil must/has to+ active verb } \\
\text { (order) } \\
\text {-Teachers could suggest others games } \\
\text { activities in each lesson } \\
\text {-17 lessons in the manual } \\
\text {-3 Repetitive sessions for each lesson. } \\
\text { Time allowed: } 45 \text { min } \\
\text {-No physical activity or preparation in } \\
\text { the lesson No. } 7 \text {. }\end{array}$ & $\begin{array}{l}\text {-SMART objectives } \\
\text { - Program focus on increasing physical competence, } \\
\text { health-related fitness, self-responsibility, and enjoy- } \\
\text { ment of physical activity for all children } \\
\text { - Lesson planification } \\
\text { - Children's participation, enjoyment, and learning } \\
\text { - Evolutive lessons } \\
\text { - Assessment } \\
\text { - Activities aiming children's development }\end{array}$ \\
\hline
\end{tabular}

Table 1 presents findings on the SOEA model applied to the ISIS manuscript. Regarding the subject, few information is available about students' characteristics. Indeed, no precision is made about gender, age, size, weight, morphology, etc., but also needs and autonomy, freedom, critical thinking or creativity. But it is assumed that they are boys according to the clothing they are wearing, haircuts (no veil or burka) and the proposed illustrations.

For the object, the presence of the ISIS flag underscores the presence of the state in education. The presence of the Basmala emphasizes the presence of religion in education. In other states, one would have to deal with both public (state) education and private education (borrowing of religion). There is no choice: religion is imposed in the education offered by the state. Interestingly, those elements are mostly present inside the general introduction and manual introduction, not later.

The Environment is where the teaching is taking place and only few references are mentioned. The "suitable court" is the only place, mentioned in each lesson ( $n=17)$ (pp. 8-24), which offers few information 
about the context and the area for implementing the physical education lessons.

Regarding the Agent, this manual seems to be a seemingly guide for the teacher to interpret it as he or she wishes. However, no information is given as to who will implement this manual. We do not know anything about this teacher, instructor or other. We know nothing about his or her training, skills or profile. Some passages suggest that the teacher would just be there to read the instructions. He is told what to do and, in this sense, he has little room for manoeuvre in terms of autonomy in his pedagogy and in the autonomy left to the students. But sometimes it is also indicated that he or she can add activities related to what is proposed. He must sometimes be master of discipline, sometimes give rules, sometimes divide the students.

Pedagogy is the relation in between the teacher (Agent) and the student (Subject). In this manual, three elements bring information about pedagogy: material used, games-activities and illustrations. It is interesting to note that the proposed illustrations do not always correspond to the exercises indicated in the manual. Thus, they do not support the teaching in any way. The general aim of the manual is clear, although it is not explicitly stated, that young children must be physically prepared to be ready to fight in the ISIS army. For example, "the student must practice the deployment and assembly exercise in the precise manner" (p. 8) or "the student must learn the hymn quoted below" (p. 13). They must be in good general physical condition to be ready for war. We therefore speak of physical fitness even though no scientific references or standards are named in connection with the development of physical fitness in young people.

Didactics is the relation between the teacher (Agent) and knowledge (Object). The general content of lessons and the compared contents of lessons 6 and 7 are two very interesting parts regarding didactics. What is clear is the logic of preparation and method to prepare student fitness. Swedish gymnastic is mentioned several times as a model to follow. However, the manual does not make any reference in this sense, and only proposes a rejection of any Western culture (p. 3), which is contradictory. Moreover, no criteria for achievement (how to make the movement) or success (how to make sure I have succeeded in the movement) is mentioned. Finally, learning and assessment, the intentions are very unclear and poorly formulated. For example: "The pupil must recall the objective of the game of tug-of-war" (p. 11) or "The pupil must recall the main objective of Swedish sports exercises" (p. 10). There is no expectation of the end of the educational cycle for students. It is not known what targets are to be achieved, either in terms of learning, or in terms of fitness or skill development. Nothing is mentioned about assessment. To achieve the overall goal, it is proposed to simply repeat the 17 lessons 3 times, but no progress is targeted in development. There is therefore no planning over several levels of mastery or between lessons. Moreover, the games proposed seem to us inadequate for the 
age group of primary school children, 1st cycle. Nothing about children's participation, enjoyment, and learning. While attention should be focused on the development of basic motor skills, the manual proposes, push-up (p. 18), abdominals (p. 18), and stretching exercises (p. 6).

\section{Discussion}

The exercise of analyzing the ISIS physical education curriculum is, to our knowledge, a first in research. It is therefore important and relevant to draw lessons and insights from this particular and challenging investigative work.

\section{Key findings}

In the present study, we observed two main findings: the logic of military use of physical education by ISIS and a teaching manual in which the content lacks reflection, criticism but above all refinement.

First of all, this study revealed a highly militarized logic of the curriculum proposed by ISIS. Since most of the training focuses on physical preparation and fitness, it is likely that the logic of militarization and preparation of future soldiers is behind the implementation of this curriculum. This logic included the appointment of physical preparation as a major focus of the textbook, the lack of freedom or creativity of the pupil, the directive role of the teacher, the use of Swedish gymnastics and highly aligned, etc. In addition, controlled and disciplined forms of teaching and grouping bears no resemblance to current international recommendations on textbook writing in physical education. According to our analysis, this textbook seems to coincide very strongly with the aims of totalitarian regimes as discussed in the introduction (Bolz, 2017; Guttmann, 2003). The soldier preparation suggested in the manual matches the ISIS needs of massive military forces to attain its objectives (Xingang et al., 2017). State control is also marked by the imposition of religion and political ideologies within the textbook itself. Finally, the teachers in this textbook look like military soldiers instead of pedagogues, which was supported by several passages in the document (Figure 7).

Second, our analysis also revealed irregularities and gaps in the content of the PE manual proposed by ISIS. Several elements related to pedagogy, didactics, learning and assessment is missing. For example, no information was given on student characteristics (e.g., age, gender, needs, enjoyment and participation), no expectations are set in terms of learning targets to be achieved, and no form of assessment is proposed at all. Similarly, the learning objectives and content do not, in their current form of writing, provide a clear idea of the 
targets to be achieved or the content to be provided to students. Our analysis also shows a marked willingness to repeat the lessons with little room left for the teacher to adapt the material to the needs of his students or to the reality of his environment. All of these elements lead us to believe that the content of the textbook was hastily constructed without a rigorous revision process, despite the fact that a writing group has been vaguely identified in previous studies (Arvisais \& Guidère, 2020a, 2020b). However, and unlike the textbooks analyzed in science (Potvin et al., 2019), we did not identify any content that would have been copied from other documents and pasted quickly into this manual.

\section{Meanings of findings - What can be understood and learned?}

This study has provided us with lessons learned about the use that ISIS has made of its physical education curriculum. The results of this study seem to point to two main perspectives: the creation by ISIS of its own education system and the use of religion for its own purposes.

On one side, ISIS has set up its own education system. This manual reflects different aspects of ISIS realities and objectives, to have the complete power on all the region in a reign of terror. In detail, the analysis of the manual revealed many inaccuracies in its content, several spelling mistakes and inappropriate use or misplacement of several illustrations. This overall lack of coherence leads us to believe the wish to rapidly establish a state by setting up, among other things, an education system to enforce its ideas and actions. This idea lines up with the conclusions of a previous study on the implementation and use of the education system by ISIS (Arvisais \& Guidère, 2020a). There is also a willingness to use physical education as a means of rapidly imposing and enforcing ideas, which align with several distinctive features of totalitarian regimes (Guttmann, 2003; Sugden \& Tomlinson, 1998). As noted by Sugden and Tomlinson (1998), sport or physical education have been used to train and represent a model or the identity that the political group wants to achieve. Guttman (2003) also mentioned several totalitarian regimes that tried, throughout history, to use sometimes sports and physical education as an instrument to control, dominate but also to train and discipline subjects according to their ambitions of power. It also seems relevant to mention that their intentions were similar but operating structures were different from previous totalitarian regimes in history. As such, the terrorist organization's "education state program," is a unique case in recent history.

On the other side, Islamic religion revisited by ISIS is, by far, one of the most prominent aspects of this manual. The terrorist group has gone so far as to create its own educational system by mixing religion and politics to serve its own interests. For example, there are misleading statements about the Prophet and 
879 inappropriate uses of passages from the Qur'an to convey their ideas of the world. The general introduction, where everything is made in the name of Allah and the Prophet, or in lesson 7, in which the pupils are to line up and sing the hymn of allegiance to the Baghdadi, are perfect examples of contradiction and misuse of religion to reach political goals. Another element that coincides perfectly with the logic of totalitarian regimes is the suppression of part of the population, in this case women. Indeed, any attempt to denunciate violence against women would be perceived as a support for the occidental imperialism (Boudjak, 2007). Boltz (2017) observed that fascist movements were obsessed with changing the habits of the population and with the training of athletes who would be loyal to the fascist cause. In their totalitarian system, education was the key to the implementation of the Revolution and the New Man was the result of fascist education, which laid as much emphasis on physical as on intellectual development. Changing minds and bodies for building a New Man were the main strategy used by the regimes (Bolz, 2008).

All those elements together let us think that ISIS potentially used its physical education under its education system to recruit and train future military soldiers. Children are easy targets for military recruitment due to their greater susceptibility to influence compared to adults (Daxhelet \& Brunet, 2013; Le Quellec Cottier, 2012). Child recruits who survive armed conflict frequently suffer of psychiatric mental illness, poor literacy and numeracy, and behavioural problems such as heightened aggression, leading to a high risk of poverty and unemployment in adulthood (Betancourt et al., 2013; Mubiri-Pondard, 2008). Psychosocial intervention by local or humanitarian workers with the youth on the field is, therefore, crucial.

\section{Recommendations}

Based on our analyses, our experiences as researchers but also as humanitarian workers, we would now like to propose several recommendations to help the work in the field. These elements can constitute tracks of reflections and solutions to help local workers to better adapt their work with the affected population: -Ensure respect for the international law of all children and adolescents, including the right to equal education and to have an inclusive education that respects the developmental needs of the child;

-Ensure that the overall development of children, including physical and mental health (i.e., enjoyment), is promoted and not only certain aspects (e.g., physical fitness);

-Verify the learning environment to promote quality education; 
-Carry out psychological and social follow-up in relation to potential trauma, brainwashing and forms of indoctrination of children and adolescents and promote their harmonious reintegration into society, potential gaps with families and communities;

-Be attentive to the lack of autonomy, creativity, participation and critical thinking skills of children who have been affected by armed conflict;

- Address the lack of fulfillment of basic physical as well as basic psychological needs of the youth;

-Verify the teaching conditions and accompany the teachers in training and pedagogical monitoring in order to provide quality education for all.

\section{Limitations}

Conducting this study was very challenging for our research team. Two limitations could be clearly identified. A first limitation comes back to the question of the translation and interpretation of this manual. First, the original manual was translated from Arabic into French by two people using a round-trip process. In fact, many words and expressions were not clear or easy to translate from Arabic into French and therefore subject to interpretation (e.g., group vs. team, competition vs. competitor, teacher vs. instructor vs monitor). Despite the precautions taken by our research team to ensure quality translation (Four Arabic-speaking authors, three authors from the Middle East), it is therefore possible that some words or expressions were misinterpreted depending on the context in which this manual was implemented. Moreover, by switching from Arabic (original document) to French (data analysis) to English (writing), and despite the research team efforts, some interpretations or explanations may have been lost or impoverished in terms of meaning (see footnote $\# 1)$.

A second limitation of this study refers to the lack of access to the field and the possibility of validating some information with quality sources. Working on a theme that includes a war context as well as an extremist group necessarily implies shortcomings in the possibility of verifying the sources of information for our analyses. In this sense, many questions remain unanswered after this analysis and several of the hypotheses we have put forward could not be verified. For example, the secondary school physical education manual was found by sources in the field but has not yet reached us for logistical reasons. Similarly, several interviewees from an ongoing study to collect testimonies on this lived reality became very silent when discussing some of the reflections on physical education and its organization by ISIS. Nevertheless, we hope that this ongoing study 
936 will help validate some of the hypotheses put forward by our analyses.

\section{Conclusion}

In summary, this study focused on what lessons can be learned from the Physical Education Curriculum under the reign of Islamic State of Iraq and Syria (ISIS). To do so, the present study conducted an unprecedented analysis of the ISIS primary school physical education curriculum describing and analyzing the context and philosophy of the document as well as its contents (calligraphy, didactic, pedagogy, learning assessment, among others). Our work reveals an incomplete and a rapidly developed textbook where several essential elements related to pedagogy, didactics, learning and assessment are missing or inconsistent. The logic of military preparation under the guise of preparing the student's physical condition is a major finding, which was developed based on religious pretexts, hijacked for political purposes. The ISIS physical education curriculum appears to be committed to an absolutist/theocratic ideological or propaganda program that, among other things, promotes the preparation of future soldiers, used in the accomplishment of the ISIS goals of dominance.

Yet, and as mentioned in the limitation section, several aspects need to be completed in future studies. Hypotheses and conclusions need to be validated with original sources using a more comprehensive investigation in the field. Finally, recommendations about secularization and the reconstruction of post-ISIS education systems are formulated but should be discussed with local partners to go further and meet their needs and those of the affected population.

\section{Declaration of interest statement}

Authors declare no conflict of interest.

\section{Acknowledgments}

Authors would like to address a special thanks to field and humanitarian workers affected by ISIS state.

\section{References}

References 
Alukah. (2020). Sharia. Retrieved from https://www.alukah.net/sharia/0/139220/

Arnaud, P. (1991). Le militaire, l'écolier, le gymnaste. Naissance de l'éducation physique en France (1869-1889). Lyon : PUL.

Arvisais, O., Bruyère, M.-H., Chamsine, C., Mahhoua, M. A., \& Guidère, M. (Submitted). The Educational Intentions of the Islamic State Through Its Textbooks. Critical Education Journal.

Arvisais, O., \& Guidère, M. (2020a). Education in conflict: how Islamic State established its curriculum. Journal of Curriculum Studies, 1-18.

Arvisais, O., \& Guidère, M. (2020b). The integration of religious elements into ISIS textbooks. Religion \& Education, 47 (2), 188-203.

Arzoumanian, N., \& Pizzutelli, F. (2003). Victimes et bourreaux : questions de responsabilité liées à la problématique des enfants-soldats en Afrique. Int'l Rev. Red Cross, 85, 827.

Bairner, A. (2017). Sport and political ideology. In A. Bairner, Kelly, J., \& Lee, J. W. (Ed.) (pp. 39-51). Routledge handbook of sport and politics: Taylor \& Francis.

Bataineh, B., Sheikh Abdullah, S. N. H., \& Omar, K. (2011). Generating an Arabic calligraphy text blocks for global texture analysis. International Journal on Advanced Science, Engineering and Information Technology, 1 (2), 150-155.

Betancourt, T. S., Borisova, I., Williams, T. P., Meyers-Ohki, S. E., Rubin-Smith, J. E., Annan, J., \& Kohrt, B. A. (2013). Research Review: Psychosocial adjustment and mental health in former child soldiers-a systematic review of the literature and recommendations for future research. Journal of Child Psychology and Psychiatry, 54 (1), 17-36.

Bolz, D. (2008). Les Arènes Totalitaires : Fascisme, Nazisme et Propagande Sportive. Paris: CNRS Editions.

Bolz, D. (2017). Sport and facism. In A. Bairner, Kelly, J., \& Lee, J. W. (Ed.), Routledge handbook of sport and politics. Park Drive, UK: Taylor \& Francis.

Boudjak, C. (2007). Un totalitarisme contre les femmes. United Kingdom: The international campain against honour killing.

Bouffard, L. A. (2005). The military as a bridging environment in criminal careers: Differential outcomes of the military experience. Armed Forces \& Society, 31 (2), 273-295.

Charland, P., Arvisais, O., Cyr, S., \& Gadais, T. (2017). Retos educativos de niños inmigrantes o refugiados. Afkar ideas: Revista trimestral para el diálogo entre el Magreb, España y Europa(55), 30-32.

Creswell, J. W. (2014). Research Design: Qualitative, Quantitative and Mixed Methods Approaches. Thousand Oaks, CA: Sage.

Daxhelet, M.-L., \& Brunet, L. (2013). Le vécu des enfants soldats. Cheminement psychique et transformations identitaires. La psychiatrie de l'enfant, 56 (1), 219-243.

Forehand, M. (2010). Bloom's taxonomy. Emerging perspectives on learning, teaching, and technology, 41 (4), 47-56.

Friedman, A., \& Smiraglia, R. P. (2013). Nodes and arcs: concept map, semiotics, and knowledge organization. Journal of documentation, 69 (1), 27-48. doi:https://doi.org/10.1108/00220411311295315

Galily, Y. (2007). Sport, politics and society in Israel: The first fifty-five years. Israel Affairs, 13 (3), 515-528.

Gentile, E. (2013). Total ideologies. In L. T. S. M. Freeden, and M. Stears (Ed.), The Oxford Handbook of Political Ideologies. (pp. 56-72). Oxford: Oxford University Press.

Gilchrist, P., \& Holden, R. (2011). Introduction: The politics of sport-community, mobility, identity. Sport in society, 14 (2), 151-159.

Goodwin, L., Wessely, S., Hotopf, M., Jones, M., Greenberg, N., Rona, R., ... Fear, N. (2015). Are common mental disorders more prevalent in the UK serving military compared to the general working population? Psychological medicine, 45 (9), 1881.

Grix, J. (2013). Sport Politics and the Olympics. Political Studies Review, 11 (1), $15-25$. doi:https://doi.org/10.1111/1478-9302.12001

Grix, J. (2016). Sport politics: An introduction. London: Macmillan International Higher Education. 
Guidère, M. (2017). L'État islamique en 100 questions. Paris : Tallandier.

Guttmann, A. (2003). Sport, politics and the engaged historian. Journal of Contemporary History, 38 (3), $363-$ 375.

Head, M., Goodwin, L., Debell, F., Greenberg, N., Wessely, S., \& Fear, N. (2016). Post-traumatic stress disorder and alcohol misuse: comorbidity in UK military personnel. Social psychiatry and psychiatric epidemiology, 51 (8), 1171-1180.

Hoberman, J. (1984). Sport and Political Ideology. Austin, TX: University of Texas Press.

Hong, F., \& Xiaozheng, X. (2002). Communist China: Sport, politics and diplomacy. The International Journal of the History of Sport, 19 (2-3), 319-342. doi: DOI: 10.1080/714001751

Houlihan, B., \& White, A. (2002). The politics of sports development: Development of sport or development through sport? : Psychology Press.

Jeannet, S., \& Mermet, J. (1998). L'implication des enfants dans les conflits armés. International Review of the Red Cross, 80 (829), 111-113.

Jézéquel, J.-H. (2006). Les enfants soldats d'Afrique, un phénomène singulier? Sur la nécessité du regard historique. [Are Child Soldiers in Africa a Unique Phenomenon?]. Vingtième Siècle. Revue d'histoire, 89 (1), 99-108. doi :10.3917/ving.089.0099

Krüger, A., \& Murray, W. (2010). The Nazi Olympics: Sport, politics, and appeasement in the 1930s. Illinois : University of Illinois press.

Lahire, B. (2007). La sociologie, la didactique et leurs domaines scientifiques. Éducation et didactique, 1 (1), 73 81.

Lahire, B., \& Johsua, S. (1999). Pour une didactique sociologique. Éducation et sociétés, 4 (2), 29-56.

Le Quellec Cottier, C. (2012). Birahima, Faustin, Johnny et les autres : l'enfant terrible à l'école de l'enfant soldat. Éthiopiques : revue socialiste de culture négro-africaine (89), 93-106.

Legendre, R. (2005). Dictionnaire actuel de l'éducation. Montréal : Guérin.

MacManus, D., Dean, K., Jones, M., Rona, R. J., Greenberg, N., Hull, L., . . Fear, N. T. (2013). Violent offending by UK military personnel deployed to Iraq and Afghanistan: a data linkage cohort study. The Lancet, 381 (9870), 907-917.

Magariños de Morentin, J. (2008). El concepto de semiótica. Instituto On-line de Semiótica.

Merkel, U. (2009). Sport, politics and reunification-A comparative analysis of Korea and Germany. The International Journal of the History of Sport, 26 (3), 406-428.

Merrill, L. L., Crouch, J. L., Thomsen, C. J., Guimond, J., \& Milner, J. S. (2005). Perpetration of severe intimate partner violence: Premilitary and second year of service rates. Military Medicine, 170 (8), 705-709.

Mingers, J., \& Willcocks, L. (2017). An integrative semiotic methodology for IS research. Information and Organization, 27 (1), 17-36.

Mubiri-Pondard, M.-A. (2008). Les aspects psychologiques chez d'ex-enfants soldats du Burundi. Archives de pédiatrie, 15 (5), 626-628.

Potvin, P., Bissonnette, M., Chamsine, C., Bruyère, M.-H., Mahhou, M. A., Arvisais, O.,... Venkatesh, V. (2019). Science Education under a Totalitarian Theocracy: Analyzing the ISIS Primary Curriculum. Journal of Research in Science, Mathematics and Technology Education, 2 (3), 179-200. doi: DOI: $10.31756 /$ jrsmte. 233

Preston, A. M., Wright, C., \& Young, J. J. (1996). Imag [in] ing annual reports. Accounting, Organizations and Society, 21 (1), 113-137.

Saint-Martin, F. (2011). Sémiologie du langage visuel. Québec : PUQ.

Saint-Martin, J. (2006). La création des Instituts régionaux d'éducation physique et le modèle du médecin gymnaste en France à la fin des années 1920. Staps(1), 7-22.

Saouter, C. (2000). Le langage visuel : essai. Montréal : XYZ Publishing.

Sarremejane, P. (2006). L'héritage de la méthode suédoise d'éducation physique en France : les conflits de méthode au sein de l'École normale de gymnastique et d'escrime de Joinville au début du XXe siècle. 
Paedagogica historica, 42 (6), 817-837.

Sugden, J., \& Tomlinson, A. (1998). Sport, politics, and identities: football cultures in comparative perspective. Journal of sport and social issues, 22 (3), 299-316.

UNESCO. (2015). Quality Physical Education. Retrieved from Paris: https://en.unesco.org/inclusivepolicylab/sites/default/files/learning/document/2017/1/231101E.pdf

UNHCR. (2018). HER TURN. It's time to make refugee girls' education a priority. Retrieved from https://www.unhcr.org/herturn/

UNICEF. (2018). How the world failed children in conflict in 2018. Retrieved from https://www.unicef.org/stories/how-world-failed-children-2018

United Nations Secretary General. (2017). Report of the Secretary General: Children and armed conflict, 2017. Retrieved from New York:

Ursano, R. J., Kessler, R. C., Stein, M. B., Naifeh, J. A., Aliaga, P. A., Fullerton, C. S., . . Zhang, B. G. (2016). Risk factors, methods, and timing of suicide attempts among U.S. Army soldiers. JAMA psychiatry, 73 (7), 741-749.

Xingang, W., Wentao, Z., \& Yulong, Y. (2017). Ideology, Global Strategy, and Development of the Islamic State and its Influence on China's "One Belt, One Road" Initiative. Journal of Global South Studies, 34 (2), $139-155$.

Yin, R. K. (2014). Case Study Research Design and Methods. Thousand Oaks, CA: Sage. 


\begin{tabular}{|c|c|c|}
\hline \multicolumn{3}{|c|}{ Contenu+illustrations des différentes pages du manuel+couverture/version abrégée } \\
\hline Veaingi apm & Le dénoté (description) & Le connoté (signification/sens) \\
\hline & $\begin{array}{l}\text { Zone (2) : C'est la zone « image/illustration ». } \\
\text { Elle occupe presque tout le centre de la page } \\
\text { de couverture. Il s'agit d'une illustra- } \\
\text { tion/«photo vitrine » pour le manuel. On note } \\
\text { une accumulation de plusieurs éléments qui y } \\
\text { sont présents. } \\
\text { C'est la photo d'une arène de combat (mise en } \\
\text { scène spectaculaire) clôturée par du grillage } \\
\text { métallique et prise en plan moyen/format } \\
\text { «paysage ». } \\
\text { Cette mise en scène illustre un genre d'entrainement } \\
\text { militaire. On y voit : trois scènes de combats à mains } \\
\text { nues en duel par des soldats de gabarit jeune (vêtus } \\
\text { d'une combinaison militaire) cagoulés, sous l'ins- } \\
\text { truction d'un arbitre à visage découvert (mais ses } \\
\text { traits sont effacés) avec un foulard noir sur la tête et } \\
\text { cachant son cou vêtu d'une combinaison militaire, un } \\
\text { agent de sécurité adulte comme ceux de l'extérieur } \\
\text { (qui entourent l'arène) portant une arme (kalachni- } \\
\text { kov) et une personne vêtue en noire dont on ne voit } \\
\text { pas ni sa tête ni son visage (caméraman) est en train } \\
\text { de filmer ou bien photographier le combat; trois dra- } \\
\text { peaux de l'ÉI accrochés en haut de la clôture, des } \\
\text { projecteurs de lumière, une affiche attachée sur le } \\
\text { grillage de l'arène, des gros sacs pesants sur les côtés } \\
\text { pour tenir la clôture. }\end{array}$ & $\begin{array}{l}\text { Par sa perspective frontale prévalente, l'illustration } \\
\text { ou l'image vitrine présente dans la page couverture } \\
\text { du manuel de préparation physique présente plu- } \\
\text { sieurs signifiants visuels, un hybride du visuel et du } \\
\text { verbal d'une mise en scène concrète d'entrainement } \\
\text { militaire photographiée avec un éclairage addition- } \\
\text { nel/valorisant en période nocturne : Les conditions } \\
\text { de lumière de la scène (les projecteurs en D.E.L.) ont } \\
\text { produit cette empreinte de remplissage décoratif de } \\
\text { la page couverture du manuel. Le plan d'ensemble } \\
\text { est assez large pour voir plusieurs personnages et élé- } \\
\text { ments de la scène, dont les combats en duel. Cela si- } \\
\text { gnifie que la photographie bénéficie d'une grande } \\
\text { puissance de vérité. } \\
\text { La présence de plusieurs personnes en action dans la } \\
\text { scène photographiée fait interpréter leurs relations. } \\
\text { Deux questions alors se posent : 1) qu'a-t-il été } \\
\text { choisi de montrer? 2) Qu'a-t-il été choisi de ne pas } \\
\text { montrer? } \\
\text { 1)***Ce qui a été choisi de nous montrer : } \\
\text { Une arène entourée de grillage et gardée par un mili- } \\
\text { taire rappelle les arènes romaines dans lesquelles } \\
\text { étaient présentés au peuple, de façon grandiose, des } \\
\text { combats à mort entre gladiateurs ou contre des ani- } \\
\text { maux. Dans une histoire plus contemporaine, cette } \\
\text { image renvoie au combat de Mixed Martial Arts } \\
\text { (MMA) : des combats impliquant une combinaison } \\
\text { d'arts martiaux, qui à ses origines, comportait peu } \\
\text { voir pas de règles (cfr Vale Tudo). Notons aussi que } \\
\text { pour un combat d'entrainement, il est surprenant que } \\
\text { les combattants portent des chaussures. } \\
\text { Dans l'axe de la simultanéité : De l'extérieur allant } \\
\text { vers l'intérieur de l'arène, on observe différentes per- } \\
\text { sonnes qui ont à voir les uns avec les autres. } \\
\text { Au premier niveau, on voit de dos des combattants } \\
\text { ou agents de sécurité (adultes selon leurs gabarits) }\end{array}$ \\
\hline
\end{tabular}


vêtus en combinaison militaire de couleur caramel portant des armes (kalachnikov) redoublent d'attention et servent à sécuriser la scène et surtout « à creuser la profondeur de champ, permettant de donner un surcroît de réalité à la scène. » : contrôle, discipline, autorité; entourant d'autres combattants un peu jeunes vêtus en combinaison militaire (vert câpre/ou vert militaire; photographiés de dos avec le regard centré sur l'arène) et collés les uns aux autres faisant une ceinture de public autour de l'arène (solidarité et fraternité entre les combattants); mais aussi en attente pour combattre à leur tour par la suite.

En haut de l'arène sont suspendus les drapeaux de l'EI. On constate une distance publique à la scène qui ne nécessite pas une participation des spectateurs.

La mise en scène de l'action d'un entrainement militaire encadré de l'EI ouvre sur trois combats à mains nus (en duel) de jeunes cagoulés vêtus en combinaison verte militaire en action de combats à des moments différents. Le port de la cagoule peut être dans le but de cacher les visages des soldats combattants ; il peut aussi appuyer l'idée de la déshumanisation et la dépersonnalisation de l'adversaire.

Ambivalence imposée : d'un côté on nous montre une fraternité, un groupe solidaire, bras dessus bras dessous, qui forme un cercle solide. De l'autre côté, on coupe les liens sociaux en cachant, par une cagoule, le visage du frère qui devient alors adversaire. Le Combat se fait sous l'instruction d'un arbitre à visage découvert (mais ses traits sont effacés) avec un foulard noir sur la tête et cachant son cou vêtu d'une combinaison militaire. Le tout est filmé par une personne qui ne porte pas d'habit/combinaison militaire. Effet cinématographique/hollywoodien.

2) ***Ce qui a été choisi de ne pas montrer :

Les visages des combattants et des agents de sécurité : ne pas les reconnaître et accentuer l'idée de la déshumanisation et la dépersonnalisation de l'adversaire.

Il s'agit d'un entrainement militaire spectaculaire et médiatisé pour des milices terroristes de l'EI comme 


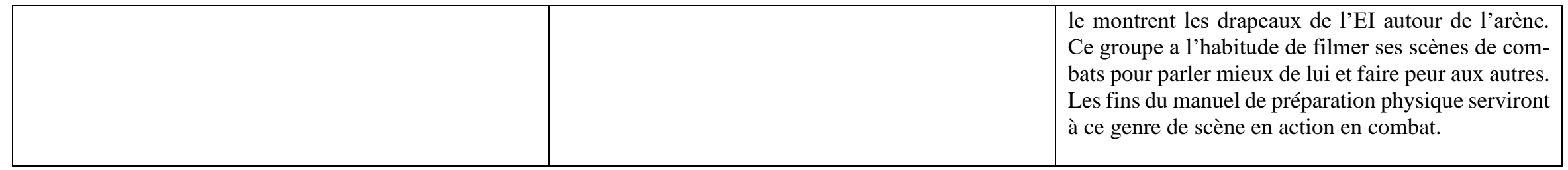

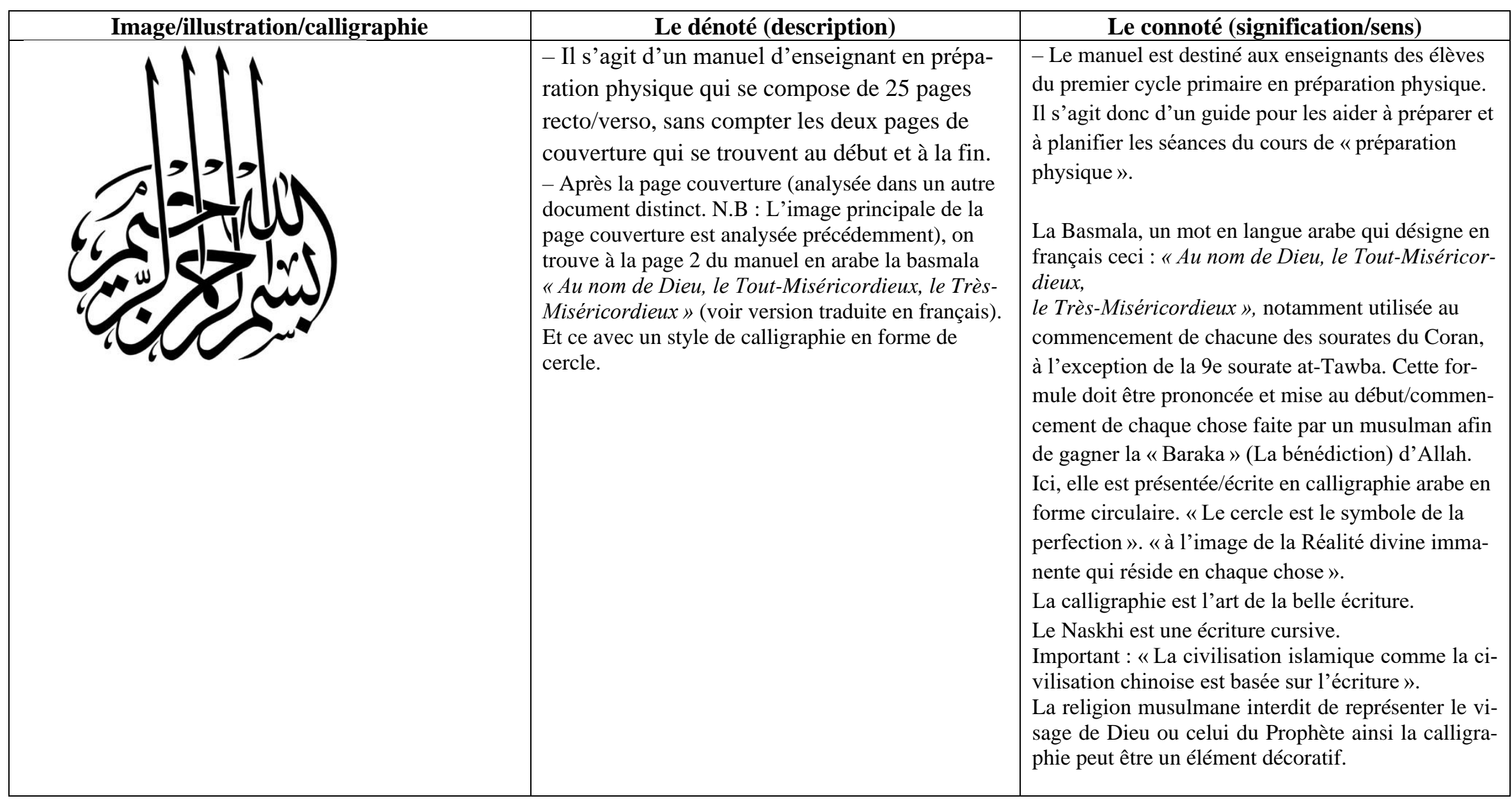




\begin{tabular}{|c|c|c|}
\hline (1) & $\begin{array}{l}\text { - À la page } 3 \text { du manuel en arabe, on trouve le } \\
\text { titre d'introduction générale suivi en arabe la } \\
\text { basmala «Au nom de Dieu, le Tout-Miséricor- } \\
\text { dieux, le Très-Miséricordieux » et ce dans un } \\
\text { style calligraphique simple et linéaire (voir ver- } \\
\text { sion traduite en français). }\end{array}$ & Idem, mais la basmala est dans un tracé rectilinéaire. \\
\hline
\end{tabular}


- À la page 5 du manuel en arabe, on trouve la partie sur l'échauffement dans un encadré similaire à celui de l'introduction ; c'est-à-dire avec des ornements en couleurs et des décorations de fleurs du côté gauche; et le drapeau de l'ÉI du côté droit. Un ajout principal entre les deux décorations florales (de tailles différentes) est celui d'une silhouette d'un militaire (chaussures, gourde d'eau, casque) en exercice de descente d'une corde. (Voir version traduite en français). À noter que ce même style est répété dans les pages suivantes : 6 et 7 qui traitent respectivement de la suite de l'échauffement et des exercices d'étirement. (Voir version traduite en français).
Idem avant avec l'ajout d'une silhouette d'un militaire qui descend en rappel pour faire penser à une force armée qui concorde avec le caractère militaire du manuel relevé à plusieurs autres endroits du manuel, mais uniforme pas en lien avec les images que l'on connait d'habitude de l'EI.

- L'association sur la même page du drapeau de l'ÉI et d'un militaire donne le ton de l'orientation de cet État et ses manières de procéder.

On est loin de l'intention de la préparation physique de veiller à la bonne santé et au bien-être. On est face à une préparation militaire.

Présence d'éléments de la nature au niveau des ornements et des décorations.

Signification des couleurs :

Vert : nature; l'espérance, la chance, la stabilité et la concentration; peut signifier l'échec et l'infortune.

Turquoise : déclinaison du bleu; couleur de la mer et du ciel; les bonnes ondes et la sagesse. (négatif : trop voyant, agressif et difficile à accorder).

Marron/brun : noble; sérénité ; douce, rassurante et presque maternelle. Signification positive: Nature; douceur; neutralité.

Rouge bordeaux : énergie, amour, détermination, joie et prouesse. (sign. négative : sang, bataille, enfer, colère).

Fleur rouge bordeaux à six pétales en forme de cœur pour exprimer l'affection et l'amour. Habituellement, c'est le chiffre impair qui est privilégié en Islam. Le modèle est très utilisé dans les bijoux et décorations, mais à cinq pétales.

D'autres informations utiles : 
motif. L'utilisation du motif engage les habitudes visuelles de l'ornementation, relatives soit, a la situation privilégiée qu'il occupera sur la surface de représentation en étant unique et centré, ou particulièrement mis en valeur par coloration ou par des matériaux sélectionnés, soit, relatives à sa répétition. Le processus de répétition d'une forme déclenche paradoxalement, comme le décrit Deleuze, un repérage des différences entre les formes pour les interpréter comme semblables ${ }^{3}$.

Le spectateur, le regardeur, est mobilisé dans sa fonction de spectation, d'imagination, de contem. plation qui découvre la dimension poétique ou ornementale, moins exigeante que le sens immé. diat. Les modifications supportées par la lettre cal-

L’ÉI : « Parmi les groupes armés qui s'opposent au pouvoir de Bagdad, l'État islamique, organisation djihadiste sunnite fondée en 2006 sous le nom d'État islamique en Irak, devient la force la plus redoutable. En juin 2014, après une série de succès militaires, il s'empare de Mossoul, la deuxième ville du pays. Son chef, Abou Bakr al-Baghdadi, se proclame alors calife, successeur de Mahomet, et obtient l'allégeance de plusieurs groupes terroristes au Moyen-

Orient, en Afrique et dans le Caucase. Le conflit, étendu à la Syrie, entraîne un nouvel exode de populations. La bataille de Tikrit, en mars 2015, marque un premier recul de l'État islamique qui continue cependant d'occuper une grande partie du nord-ouest de l'Irak.

Le nouveau gouvernement formé en septembre 2014, dirigé par Haïder al-Abadi, du Parti islamique Dawa, ouvert aux partis chiites, sunnites et kurdes, semble avoir beaucoup de mal à s'imposer face à des alliés aux intérêts divergents : milices kurdes des peshmerga et du PKK, milices tribales sunnites, milices des partis chiites, ingérence de l'Iran et de la Coalition internationale en Irak et en Syrie"l " 


\begin{tabular}{|c|c|c|}
\hline Image/illustration/calligraphie & Le dénoté (description) & Le connoté (signification/sens) \\
\hline |الخطة آدربس رقم 1 & $\begin{array}{l}\text { - À la page } 8 \text { du manuel en arabe, le titre } \\
\text { de la leçon est mentionné avec des lettres } \\
\text { imprimées en blanc dans un encadré gris } \\
\text { un peu foncé avec une décoration du côté } \\
\text { droit sous la forme de trois hexagones ré- } \\
\text { guliers et qui s'entrecoupent : Le premier } \\
\text { de couleur grise claire, où s'est écrit le } \\
\text { mot «État» en arabe avec un style parti- } \\
\text { culier de calligraphie arabe de couleur } \\
\text { noire. Le deuxième encadré de couleur } \\
\text { mauve ou violet porte le mot « du Cali- } \\
\text { fat » en calligraphie arabe (couleur } \\
\text { blanche) et sur le troisième hexagone de } \\
\text { couleur noire s'est écrit « Islamique». } \\
\text { À noter que ce même style est répété/re- } \\
\text { produit dans toutes les pages des diffé- } \\
\text { rentes leçons présentes dans le manuel } \\
\text { (c'est-à-dire de la page } 8 \text { à la page } 24 \text {; } \\
\text { c'est juste le numéro de la leçon qui } \\
\text { change). } \\
\text { (Avis de Mazen ici sur l'aspect de la pré- } \\
\text { paration physique trop demandée en ré- } \\
\text { férence aux formes hexagonales pré- } \\
\text { sentes dans les titres de chaque leçon) }\end{array}$ & $\begin{array}{l}\text { La présence de trois hexagones confirme l'idée va- } \\
\text { lorisante des chiffres impairs en Islam. } \\
\text { L'hexagone est trouvable dans la nature (exemple } \\
\text { ruche d'abeille : c'est par cette association que } \\
\text { l'hexagone est devenu symbole de travail, de la ri- } \\
\text { gueur, de l'organisation, de persévérance et de l'ef- } \\
\text { fort collectif); autre exemple : le logo hexagonal } \\
\text { depuis } 1977 \text { de Desjardins illustre tout ça. } \\
\text { La forme hexagonale est utilisée dans les métiers } \\
\text { liés aux bâtiments et les métiers manuels en général } \\
\text { pour symboliser la difficulté des métiers. } \\
\text { La signification des couleurs : } \\
\text { - Violet couleur de royauté (historiquement, car } \\
\text { elle était rare et coûteuse : mélange entre le bleu et } \\
\text { le rouge). } \\
\text { - Noir : noirceur, obscurité, } \\
\text { - Gris : mélange entre noir et blanc, couleur neutre, } \\
\text { utilisée pour mettre en valeur d'autres couleurs. } \\
\text { Teinte fade associée à la tristesse et à la solitude. } \\
\text { Nuances : Gris foncé et gris clair. } \\
\text { Blanc : pureté et l'innocence. Ici mise en valeur par } \\
\text { le gris un peu foncé. }\end{array}$ \\
\hline
\end{tabular}




\begin{tabular}{|l|l|l|}
\hline Image/illustration/calligraphie & \multicolumn{1}{|c|}{ Le dénoté (description) } & \multicolumn{1}{|c|}{ Le connoté (signification/sens) } \\
\hline & $\begin{array}{l}\text { À la page } 8 \text { du manuel en arabe, sous } \\
\text { l'encadré de la partie principale de la le- } \\
\text { çon numéro 1, on trouve deux illustra- } \\
\text { tions. } \\
\text { L'illustration 1: } \\
\text { On y voit plusieurs formes ovales de } \\
\text { groupe vu d'en haut (photo prise avec un drone) } \\
\text { avec un instructeur-professeur-moniteur-ensei- } \\
\text { gnant en avant qui leur fait face, qui dirige et en- } \\
\text { cadre des élèves (plus jeunes que lui) qui sont pla- } \\
\text { cés en ordre et en ligne. Les élèves font face à l'ins- } \\
\text { tructeur et se tiennent droits (référence à l'armée } \\
\text { militaire). Les éléments formant le groupe sont de } \\
\text { plus petites tailles que l'élément leur faisant face. } \\
\text { On aurait donc à faire à une représentation d'un } \\
\text { groupe d'élèves face à un enseignant. La disposi- } \\
\text { tion du groupe est très structurée. Chaque individu des petites formes circulaires de } \\
\text { est aligné avec les autres. Représentation très or- } \\
\text { donnée d'un groupe. Cette disposition connote une } \\
\text { formation d'un rang militaire et non scolaire. Une } \\
\text { disposition dans un cadre scolaire serait plutôt re- } \\
\text { présentée en demi-cercle d'élèves face à un ensei- } \\
\text { gnant. Il s'agit d'une illustration qui n'est pas pé- } \\
\text { dagogique, mais plutôt militaire !!! }\end{array}$ \\
\hline
\end{tabular}

\begin{tabular}{|c|c|c|}
\hline Image/illustration/calligraphie & Le dénoté (description) & Le connoté (signification/sens) \\
\hline & $\begin{array}{l}\text { L’illustration } 2 \text { : pour accompagner le petit jeu } \\
\text { proposé dans le cadre de cette leçon. } \\
\text { On y voit des figurines de petits garçons avec } \\
\text { les cheveux noirs vêtus avec un habit (sorte de } \\
\text { tunique longue en brun+pantalon large mou- } \\
\text { tarde) et de petits chaussons noirs qui se sui- } \\
\text { vent dans une action de mouvement (course ou } \\
\text { marche). Par contre les traits de leurs visages } \\
\text { sont effacés. } \\
\text { À noter que ce même style est répété/reproduit } \\
\text { dans les pages suivantes du manuel (10, } 11 \text {, } \\
20 \text { et } 21 \text { ). } \\
\text { N. B. La couleur de peau est blanche/rosée }\end{array}$ & $\begin{array}{l}\text { - Cette illustration d'enfants qui courent dans diffé- } \\
\text { rentes positions et qui portent visiblement un habit } \\
\text { (il s'agit probablement traditionnel de la région ou } \\
\text { bien faisant référence à l'identité vestimentaire de } \\
\text { l'ÉI) qui n'est pas adapté ou recommandé pour l'ac- } \\
\text { tivité physique et même la préparation militaire (for- } \\
\text { tement soulignée depuis la page couverture du ma- } \\
\text { nuel) n'a pas de fonction particulière si ce n'est de la } \\
\text { décoration pour le manuel. Il n'est pas utile avec les } \\
\text { consignes proposées dans chaque leçon. On ne } \\
\text { cherche pas à décrire un mouvement ou les sé- } \\
\text { quences d'un mouvement ou une organisation. } \\
\text { La religion musulmane interdit de représenter le vi- } \\
\text { sage de Dieu ou celui du/des Prophètes. Le visage } \\
\text { effacé du personnage : Est-ce qu'en lien avec les re- } \\
\text { présentations sacrées? Anonymisation des person- } \\
\text { nages? Ne pas donner de visage pour un « citoyen » } \\
\text { de l'ÉI pour ne pas le reconnaître? }\end{array}$ \\
\hline
\end{tabular}




\begin{tabular}{|c|c|c|}
\hline Image/illustration/calligraphie & Le dénoté (description) & Le connoté (signification/sens) \\
\hline
\end{tabular}




\begin{tabular}{|c|c|c|}
\hline Image/illustration/calligraphie & Le dénoté (description) & Le connoté (signification/sens) \\
\hline & $\begin{array}{l}\text { - À la page } 12 \text { du manuel en arabe, sous l'en- } \\
\text { cadré de la partie principale de la leçon nu- } \\
\text { méro 5, et parallèlement aux consignes du saut } \\
\text { continu sur place on trouve l'illustration } 1 \text { sui- } \\
\text { vante : } \\
\text { Une figurine d'un garçon (vêtu avec un habit [sorte } \\
\text { de tunique longue verte câpre+pantalon/pantacourt } \\
\text { [s'arrête au-dessus de la cheville] large vert clair] } \\
\text { +couvre chef bleu et de petits chaussons/souliers } \\
\text { noirs; les traits du visage sont effacés; une coiffe ou } \\
\text { bonnet bleu ciel; les bras tendus latéralement et ses } \\
\text { jambes fléchies). }\end{array}$ & $\begin{array}{l}\text { Enfant habillé en tenue (un habit probablement tradition- } \\
\text { nel de la région ou bien faisant référence à l'identité ves- } \\
\text { timentaire de l'ÉI) qui n'est pas adaptée ou recomman- } \\
\text { dée pour l'activité physique et même la préparation mi- } \\
\text { litaire (fortement soulignée depuis la page couverture du } \\
\text { manuel) de couleurs sombres (sans traits de visage et } \\
\text { portant une coiffe bleu clair). Mais aucun autre élément } \\
\text { n'apparaît sur la photo. Sa tenue a changé de couleur, } \\
\text { mais reste dans les tons foncés. } \\
\text { - Encore une fois, l'illustration seule n'est pas utile à } \\
\text { l'enseignant. Elle correspond à ce qui est décrit dans la } \\
\text { leçon (saut sur place), mais ne soutient pas la compré- } \\
\text { hension d'un mouvement ou une séquence de mouve- } \\
\text { ment ou une organisation. L'illustration n'apporte rien } \\
\text { à l'enseignant en termes de compréhension et d'appli- } \\
\text { cation de la leçon. Sa fonction est décoratrice ou encore } \\
\text { parachutée !! }\end{array}$ \\
\hline
\end{tabular}

\section{- À la page 12 du manuel en arabe, sous l'en-} cadré de la partie principale de la leçon numéro 5 , on trouve l'illustration 2 suivante : - L'illustration 2 : On la trouve parallèlement au petit jeu du tir à la corde.

6 figurines de garçons (2 équipes en face à face qui s'opposent au tir à la corde ( 3 de chaque côté (vêtus respectivement avec un habit [sorte de tunique longue verte câpre+pantalon/pantacourt (s'arrête audessus de la cheville) large noir ou gris foncé équipe gauche; et l'équipe droite : sorte de tunique longue bourgogne+pantalon (idem) large noire ou gris foncé] et de petits chaussons/souliers noirs ; les traits du visage sont effacés).

Voyez-vous une peau noire pour le premier personnage orange et le dernier personnage vert?

\section{Le connoté (signification/sens)}

- L'illustration représente l'organisation du jeu proposé dans la leçon 5. L'illustration est utile à la compréhension du jeu par l'enseignant. On a affaire à un jeu de compétition. Deux équipes. Celles qui gagnent et l'équipe qui fait tomber l'autre. L'équipe/le groupe travaille ensemble contre un ennemi/rival commun, à savoir l'autre équipe/groupe. Ce jeu illustre bien l'esprit de l'introduction générale. Il s'agit donc de deux équipes qui tiennent une corde et semblent courir les uns vers les autres (pas le but du tir à la corde) le dernier ne tient la corde que d'une main. Illustration pas claire et peu en lien avec l'objectif de l'exercice qui est de se rappeler du but du jeu du tir à la corse. Ce but n'est pas mentionné dans le texte.

- Les équipes sont formées de manière aléatoire. Notre ami peut donc devenir notre rival. 


\begin{tabular}{|c|c|c|}
\hline Image/illustration/calligraphie & Le dénoté (description) & Le connoté (signification/sens) \\
\hline 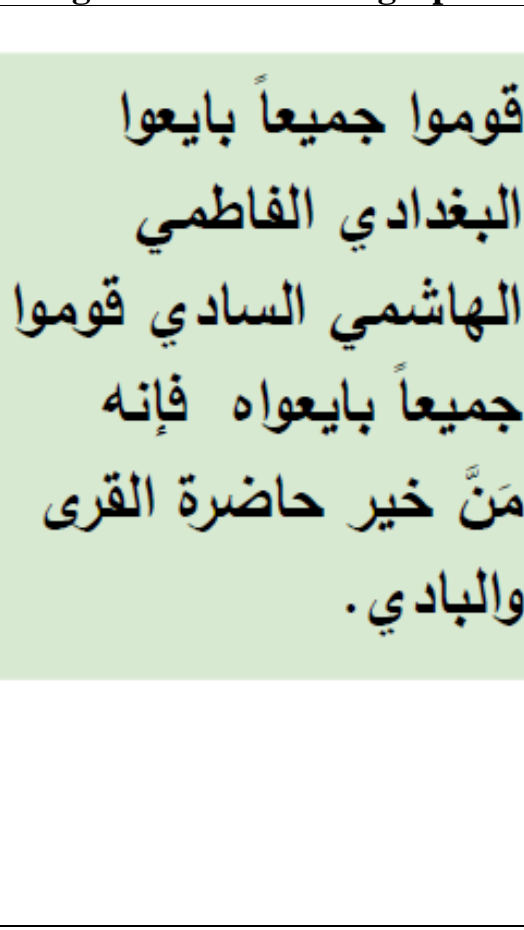 & $\begin{array}{l}\text { - À la page } 14 \text { du manuel en arabe, sous l'en- } \\
\text { cadré de la partie principale de la leçon nu- } \\
\text { méro } 7 \text {, et parallèlement aux consignes du petit } \\
\text { jeu on trouve l'illustration suivante : } \\
\text { Dans un encadré vert pâle, et avec des lettres impri- } \\
\text { mées en arabe s'est écrit l'hymne suivant traduit en } \\
\text { français : Allez tous, faites l'acte d'allégeance au } \\
\text { Baghdadi, le Fatimide, le Hachimiste, le maître. } \\
\text { Allez tous, faites-lui l'acte d'allégeance il est le meil- } \\
\text { leur représentant des villages et de la campagne. }\end{array}$ & $\begin{array}{l}\text { La récitation d'un hymne proposé comme jeu dans la le- } \\
\text { çon } 7 \text { n'implique pourtant pas d'activité physique à pro- } \\
\text { prement parler si ce n'est une marche régulière guidée } \\
\text { par un chef de file. Cette leçon ressemble plus à une ac- } \\
\text { tivité proposée dans un entrainement militaire qu'à un } \\
\text { «jeu » dans un cours d'activité physique. Encore une } \\
\text { fois, la santé et le bien-être ne sont pas visés. On vise } \\
\text { plutôt un endoctrinement. } \\
\text { - Cet hymne ne fait pas référence à Allah, en tant que } \\
\text { figure la plus importante comme c'est le cas dans l'in- } \\
\text { troduction générale, mais place le «Baghdadi » comme } \\
\text { «maître » ou « calife ». Ceci confirme le constat de l'em- } \\
\text { preinte religieuse et militaire de l'ÉI dans ce manuel de } \\
\text { préparation physique. } \\
\text { - La partie « jeu» est présentée comme modifiable dans } \\
\text { les plans de leçon. Pourtant dans ce cas, l'objectif de la } \\
\text { leçon est en lien direct avec le jeu et non pas la partie } \\
\text { principale comme c'est le cas dans les autres leçons (sauf } \\
\text { leçon } 5 \text { et } 11 \text { ) >Incohérence. } \\
\text { Remarque dans la leçon } 13 \text {, l'objectif renvoie à l'étire- } \\
\text { ment et non à la partie principale ou au jeu. De par son } \\
\text { objectif, cette leçon n'est nullement pédagogique et ne } \\
\text { sert à rien dans la préparation physique. }\end{array}$ \\
\hline Image/illustration/calligraphie & Le dénoté (description) & Le connoté (signification/sens) \\
\hline & $\begin{array}{l}\text { - À la page } 15 \text { du manuel en arabe, sous l'encadré } \\
\text { de la partie principale de la leçon numéro } 8 \text {, on } \\
\text { trouve l'illustration } 1 \text { suivante : } \\
\text { Elle se trouve parallèlement aux consignes de } \\
\text { la roulade avant sur un tapis. Il s'agit d'une fi- } \\
\text { gurine de garçon vêtu en tunique grise, panta- } \\
\text { lon large en brun, mettant un foulard en rouge } \\
\text { bordeaux et des chaussons noirs illustrés dans } \\
\text { deux positions } 1 / \text { assise et } 2 / \text { en train tourner sur } \\
\text { le dos sur genre de tapis par terre avec l'indica- } \\
\text { tion d'une flèche en bleu qui fait le lien entre } \\
\text { les deux positions. }\end{array}$ & $\begin{array}{l}\text { Cette illustration décrit le mouvement de roulade attendu } \\
\text { dans la leçon. L'illustration a pour fonction de représen- } \\
\text { ter les séquences d'un mouvement de roulade. On voit } \\
\text { un exercice ce culbuto ou l'élève en habit (le même que } \\
\text { les autres illustrations et pas adapté à l'activité physique) } \\
\text { doit rouler sur son dos et se relever sur les pieds en se } \\
\text { tenant les jambes. Exercice de gymnastique pour } \\
\text { s'échauffer et peu représentatif de la roulade avant (ni } \\
\text { gymnastique avec pose de mains pour protéger la chute } \\
\text { ni judo avec frappe de la main sur le côté pour amortir la } \\
\text { chute) } \\
\text { On ne voit pas de tapis sur l'image alors que dans le } \\
\text { texte, l'utilisation du tapis est mentionnée. Le texte ne } \\
\text { donne pas d'explication sur comment enseigner la rou- } \\
\text { lade (étapes) et l'illustration est trop sommaire pour pou- } \\
\text { voir soutenir l'enseignant dans cette tâche. Il faudrait y }\end{array}$ \\
\hline
\end{tabular}




\begin{tabular}{|c|c|c|}
\hline Image/illustration/calligraphie & Le dénoté (description) & Le connoté (signification/sens) \\
\hline & $\begin{array}{l}\text { - À la page } 15 \text { du manuel en arabe, sous l'encadré } \\
\text { de la partie principale de la leçon numéro } 8 \text {, on } \\
\text { trouve l'illustration } 2 \text { suivante : } \\
\text { on la trouve parallèlement aux consignes du petit } \\
\text { jeu. On y voit trois couloirs avec des obstacles, des } \\
\text { plots, des drapeaux et une figurine d'un garçon vêtu } \\
\text { en tunique violette, pantalon large gris noir, et des } \\
\text { chaussons noirs. Il était en mouvement avec les } \\
\text { jambes en avant en train de courir. }\end{array}$ & $\begin{array}{l}\text { Cette illustration représente un personnage (garçon) } \\
\text { dans l'organisation d'un parcours. Elle est utile à l'en- } \\
\text { seignant. Le matériel utilisé/représenté est très som- } \\
\text { maire. L'exercice d'obstacles qui n'est pas clair du sens } \\
\text { ni des choses à faire en lien avec les obstacles. Les obs- } \\
\text { tacles ne sont pas clairs non plus (barrières, haies, } \\
\text { lignes au sol, roches, cônes ?) pas clair ce que l'élève } \\
\text { doit vraiment réaliser ni dans quels ordres. }\end{array}$ \\
\hline
\end{tabular}

\begin{tabular}{|c|c|c|}
\hline Image/illustration/calligraphie & Le dénoté (description) & Le connoté (signification/sens) \\
\hline
\end{tabular}




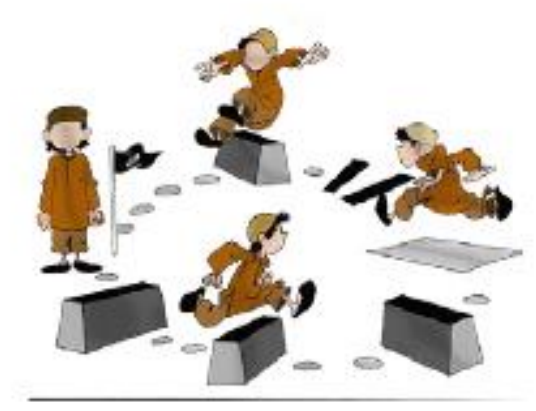

- À la page 16 du manuel en arabe, sous l'encadré de la partie principale de la leçon numéro 9, on trouve l'illustration 2 suivante : - L'illustration 2 : On la trouve parallèlement au petit jeu. Il s'agit de figurines de petits garçons avec les cheveux noirs qui sortent d'une coiffe (bonnet moutarde) vêtue avec un habit (sorte de tunique longue en brun+pantalon large moutarde ou camelle) et de petits chaussons noirs qui se suivent dans une action de mouvement (en train de courir pour surmonter les plots) dans un parcours circulaire avec un drapeau noir de l'EI indiquant la fin du parcours ou la ligne d'arrivée/ou la ligne de départ (pas d'indication de départ ou de fin).
- Cette illustration représente un parcours d'obstacles (que l'élève en tenue de l'EI doit sauter, franchir, parcourir... mais les consignes et les obstacles ne sont pas clairs, ni le matériel) qui n'est pas mentionné dans le texte de cette leçon. Le jeu propose une course rapide, mais pas de parcours d'obstacles. Cette figure aurait eu une utilité pour l'enseignant (organisation du parcours) si le contenu de la leçon était en lien avec l'illustration, ce qui n'est pas le cas. Cette erreur de placement pose des questions sur la qualité du manuel et la relecture. $\mathrm{Si}$ des fautes de frappe peuvent passer inaperçues dans une relecture, une image qui n'est pas en lien avec un texte est une erreur assez majeure. Cette erreur indique que le manuel a été fait à la hâte.

- Il y a un rappel de la présence/omniprésence de l'état par le drapeau de l'ÉI. Le contexte du déroulement de l'activité et le but militaire ultime de la préparation physique.

\begin{tabular}{|c|c|c|}
\hline Image/illustration/calligraphie & Le dénoté (description) & Le connoté (signification/sens) \\
\hline
\end{tabular}




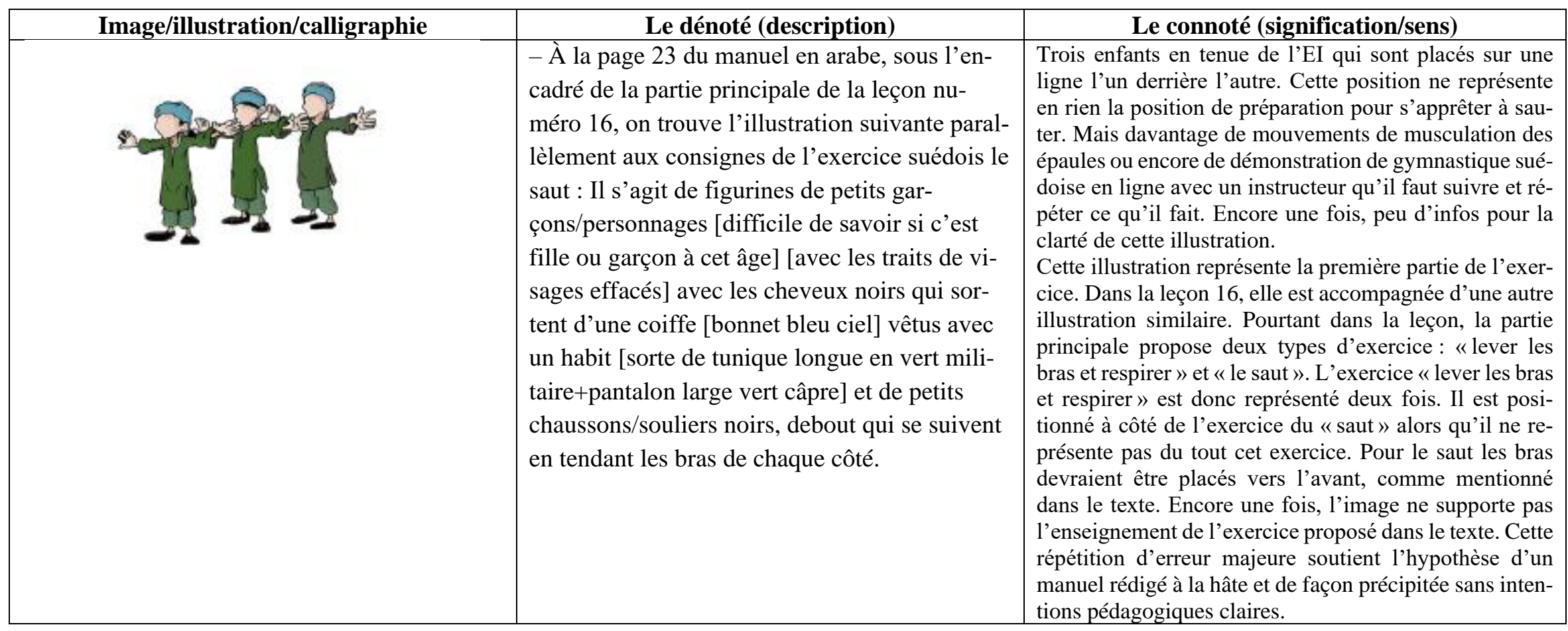

\begin{tabular}{|l|l|l|}
\hline Image/illustration/calligraphie & \multicolumn{1}{|c|}{ Le dénoté (description) } & \multicolumn{1}{|c|}{ Le connoté (signification/sens) } \\
\hline & $\begin{array}{l}\text { À la page 24 du manuel en arabe, sous l'en- } \\
\text { cadré de la partie principale de la leçon nu- } \\
\text { méro 17, on trouve les illustrations suivantes : } \\
- \text { l'illustration 1 : On la trouve parallèlement } \\
\text { aux exercices suédois : Étirement des ischio- } \\
\text { cice proposé dans le texte. Cette position ne représente } \\
\text { pas l'étirement des ischiojambiers (tronc devrait être } \\
\text { abaissé sur les jambes pour toucher les pieds), mais da- } \\
\text { vantage un enfant qui tient un cercle comme un volant } \\
\text { d'une voiture pour conduire. Que signifie la ligne noire } \\
\text { en arrière et pourquoi les 2 pieds sont joints ensemble? } \\
\text { Pas d'explications concrètes ni rationnelles. Le cercle } \\
\text { jenu par le personnage n'est aucunement mentionné dans } \\
\text { lame texte. Encore une fois, cette erreur majeure soutient } \\
\text { Il s'agit d'une figurine de garçon [aux traits de } \\
\text { visage effacés] assis par terre et vêtu en tu- } \\
\text { nique bleu foncé, pantalon large vert, portant } \\
\text { des chaussons noirs et tenant un cercle bleu. Il } \\
\text { porte une coiffe verte. Derrière le personnage, } \\
\text { tions parachutées pour combler l'espace blanc dans les } \\
\text { pages du manuel. }\end{array}$ \\
\hline
\end{tabular}




\begin{tabular}{|c|c|c|}
\hline Image/illustration/calligraphie & Le dénoté (description) & Le connoté (signification/sens) \\
\hline & $\begin{array}{l}\text { - L'illustration } 2 \text { : On la trouve parallèlement } \\
\text { au petit jeu. Il s'agit de figurines de petits gar- } \\
\text { çons avec les cheveux noirs qui sortent d'une } \\
\text { coiffe (bonnet vert) vêtus avec un habit (sorte } \\
\text { de tunique longue en vert câpre+pantalon large } \\
\text { vert clair) et de petits chaussons noirs avec un } \\
\text { «ballon attaché au pied »/parlerait-on de tâches } \\
\text { ou déjà de ballons? (les ballons sont de diffé- } \\
\text { rentes couleurs fluorescentes : rose, jaune et } \\
\text { vert) qui se suivent dans une action de mouve- } \\
\text { ment (en train de courir) dans un parcours cir- } \\
\text { culaire fermé tracé en noir./personnages qui } \\
\text { courent dans un espace délimité par un cercle. }\end{array}$ & $\begin{array}{l}\text { - Cette illustration représente le jeu proposé dans le } \\
\text { texte. Le cercle de jeu parait très étroit pour les } 3 \text { enfants } \\
\text { qui jouent à péter le ballon de l'autre attaché au pied. Jeu } \\
\text { difficile à organiser pour tenir le ballon au niveau de la } \\
\text { cheville dont, j'imagine, l'objectif est de faire exploser } \\
\text { le ballon des autres avec son pied. Peu d'informations } \\
\text { sont fournies en lien avec le jeu. } \\
\text { Néanmoins, il n'est pas fait mention d'un espace déli- } \\
\text { mité à l'intérieur duquel le jeu se déroule. L'illustration } \\
\text { renforce donc le texte et soutient l'enseignant dans l'or- } \\
\text { ganisation du jeu. Cette illustration a un côté plus lu- } \\
\text { dique que les autres illustrations du manuel. Les couleurs } \\
\text { vives des ballons soutiennent probablement cette im- } \\
\text { pression. Cependant, le jeu proposé consiste à nouveau } \\
\text { en une compétition. Il n'est pas question d'équipe, c'est } \\
\text { chacun pour soi et il y a un seul gagnant. Si dans certains } \\
\text { jeux proposés dans le manuel, il y a une forme de coo- } \\
\text { pération à travers la formation d'équipe/groupe, une idée } \\
\text { de réalisation commune (même si le but est de vaincre le } \\
\text { rival), elle est totalement absente du jeu ici proposé. La } \\
\text { morale transmise par ce jeu « que le meilleur gagne» et } \\
\text { «chacun pour soi ». }\end{array}$ \\
\hline
\end{tabular}




\begin{tabular}{|c|c|c|}
\hline Image/illustration/calligraphie & Le dénoté (description) & Le connoté (signification/sens) \\
\hline & $\begin{array}{l}\text { - À la fin du manuel (page } 25 \text { du manuel en } \\
\text { arabe), on trouve une phrase écrite en calli- } \\
\text { graphie arabe : «Fait par la louange à Al- } \\
\text { lah» (voir version traduite en français). }\end{array}$ & $\begin{array}{l}\text { - Retour à la calligraphie arabe Naskhi pour mar- } \\
\text { quer la fin du document. L'expression : «Fait par } \\
\text { la louange à Allah». Elle est prononcée ou dite } \\
\text { pour remercier Dieu d'avoir terminé ou fait ce tra- } \\
\text { vail ou encore ce manuel. Elle en forme circulaire. } \\
\text { «Le cercle est le symbole de la perfection ». «À } \\
\text { l'image de la Réalité divine immanente qui réside } \\
\text { en chaque chose». }\end{array}$ \\
\hline
\end{tabular}


L'analyse du contenu des leçons est basée sur l'analyse de nuages de mots des sous-parties des 17 leçons regroupées ensemble. Ces nuages ont été générés grâce au logiciel NVivo12. Le format, la couleur, la police et l'orientation des mots dans le nuage, n'ont fait l'objet d'aucune manipulation de la part des chercheurs et ont été généré automatiquement par le logiciel. Pour analyser les nuages de mots, une analyse sémiologique (REF) se centrant sur le dénoté et le connoté a été réalisée. Celle-ci est assortie d'une analyse des fréquences inspirée de l'analyse lexicométrique de sorte à analyser les occurrences des mots dans les textes traduits en français de la version arabe du "manuel de préparation physique ». Cette façon de procéder a permis aux codeurs de donner plus de sens au texte, de mieux le comprendre et de focaliser l'attention sur les différents mots-clés mis en exergue par Nvivo12. Les nuages de mots ont permis de représenter visuellement la prépondérance de certains mots dans les textes des différentes pages composant le manuel.

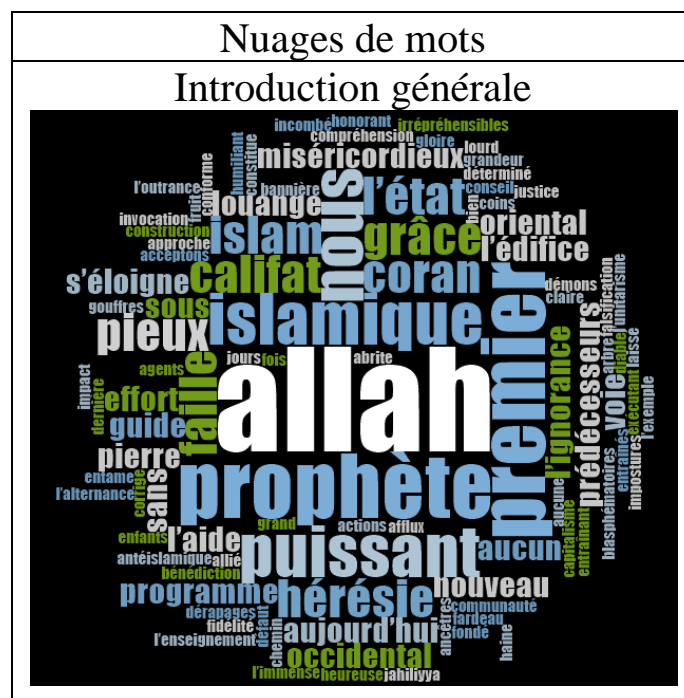

\section{Dénoté/description} l'introduction générale occupe toute la page et débute par la Basmala : « Au nom d'Allah le tout miséricordieux, le très miséricordieux ». Le texte est écrit avec une typographie arabe différente du style utilisé dans le reste des pages du manuel et prend la forme classique d'un discours qui pourra être prononcé à l'oral.

- Le mot le plus utilisé est Allah (8). De nombreuses références à Allah, à sa grâce (3), à son aide (2) et à sa bénédiction (1)

- Les mots mis en exergue sont : premier (5), prophète (5), islamique (4), nous (4), puissant (4)

- Un second groupe de mots (3) se démarque : califat, Coran, faille, grâce, hérésie, Islam, l'état, pieux

- Dans un troisième groupe de mots, on trouve des références à l'ennemi : cités deux fois : l'ignorance, occidental, oriental. Cités une fois : blasphématoires, capitalisme, diable, défaut, démons, dérapages, falsification, haine, humiliant, impostures, irrépréhensibles, justice, mécréants, polythéisme, ruse, socialisme, trucage, vicieux, victoire, épée

\begin{tabular}{|l|}
\multicolumn{1}{|c|}{ Connoté/sens } \\
- L'introduction générale (type avant-propos) présente \\
dans ce manuel est assez inhabituelle pour un manuel \\
scolaire ou didactique. En effet, on y retrouve, le dis- \\
cours typique de l'ÉI teinté de haine, sur un fond sail- \\
lant de religion définie selon l'ÉI : «L'enseignement \\
islamique; un nouveau programme». La référence à la \\
religion est omniprésente pour guider l'éducation. Tout \\
est fait au nom d'Allah, mais avec une « vision claire» \\
(p.3) qui définit l'identité et l'objectif de l'ÉI : «ni \\
orientale ni occidentale, mais coranique prophétique \\
qui s'éloigne des passions, des hérésies et des impos- \\
tures émanant des missionnaires du socialisme oriental \\
et du capitalisme occidental ou des agents des partis et \\
mouvements vicieux aux quatre coins du monde » \\
(p.3). \\
- Le texte se présente comme un document religieux qui \\
intègre le programme de condition physique. \\
- Un champ lexical définissant l'ÉI : L'ÉI=l'État du Cali- \\
fat=l'édifice du Califat. \\
- À la fin de l'introduction générale, les efforts fournis \\
afin de rédiger ce manuel sont reconnus et une ouver- \\
ture ou bien prédisposition à la critique, conseil et mo- \\
dification venant de « de tout partisan (allié/ami)» est \\
suggérée. Cette dernière précision indique que toute \\
critique n'est pas la bienvenue malgré une soi-disant \\
ouverture.
\end{tabular}




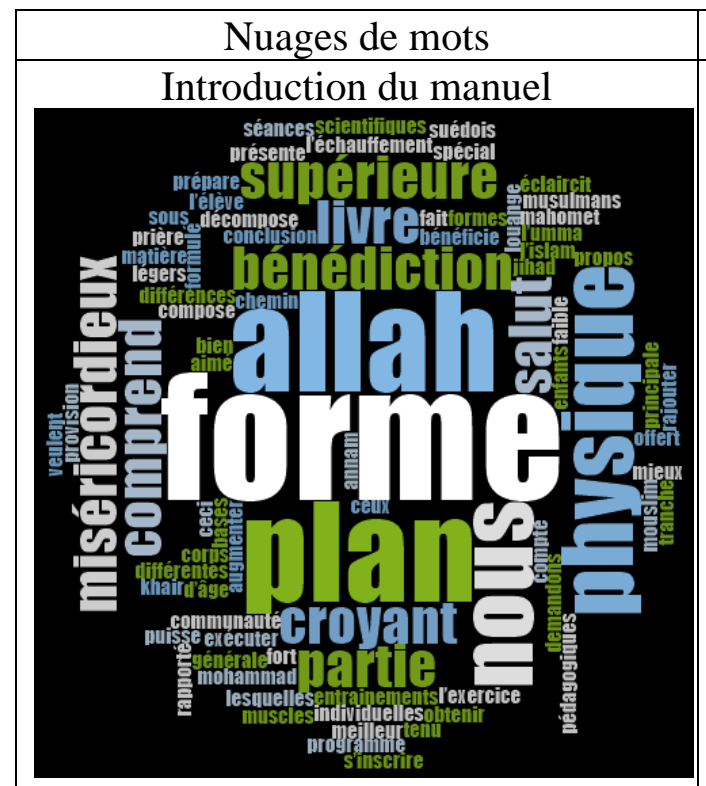

Dénoté/description l'introduction générale occupe toute la page et débute par la basmala : « Au nom d'Allah le tout miséricordieux, le très miséricordieux ». Le texte est écrit avec les lettres d'imprimerie et non pas une calligraphie spéciale.

- Le mot « forme» (cité 5 fois) est prédominant. La « forme » est associée trois fois au mot «physique».

- Un premier groupe de mots est formé des mots suivants : Allah (4), plan (4), nous (3) et physique (3).

- Un second groupe de mots est constitué de mots cités deux fois : bénédiction, croyant, livre, miséricordieux, partie, salut, supérieure. Ce dernier mot caractérise la «forme physique ».

- Dans un troisième groupe de mots cités une fois, on trouve des références telles qu'Annam, enfants, entrainements, faible, fort, Jihad, Khair, l'Islam, l'Umma, l'élève, Mahomet, Mohammad, Mouslim, musulmans, programme, pédagogiques, scientifiques, suédois, âge, individuelles
- Cette introduction est plus spécifique au contenu du manuel : « un programme spécial pour la forme physique » pour « une forme supérieure. Elle présente le programme, proposant des plans de leçons, favorisant un objectif et une intention unique la forme/condition physique supérieure.

- Ce texte d'introduction présente le lien direct tissé par l'ÉI entre la forme physique et la religion, en faisant foi des propos du prophète Mohammad/Mahomet (SAW: prière et salut sur lui). Cependant, ces mots n'ont pas été prononcés dans le sens mentionné dans ce manuel : nullement la force et la forme physique n'ont été mentionnées par le prophète (Source). Nous constatons le détournement de sens aux fins du manuel et plus largement de l'ÉI. Le message religieux est manipulé pour soutenir la crédibilité.

- Les attentes de fin de formation ne sont pas claires : qui veut-on former, pourquoi et à quelles fins? Ceci dit, en se référant à la page de couverture du manuel, à l'introduction générale et la mention directe du terme « Jihad », les fins du manuel se précisent et sous-entendent la formation de la condition physique d'un futur combattant ou soldat pour se battre pour l'ÉI contre les ennemis de l'Islam au sens où l'ÉI les définit. On serait donc face à une préparation physique militaire aux fins de l'ÉI.

- Le manuel dit être formulé sur des bases scientifiques et pédagogiques. Cependant, aucune référence bibliographique ou nom d'expert n'est cité.

- Le manuel dit tenir compte de l'âge et des différences individuelles mais ne donnent pas de détails sur la nature de celles-ci ou comment en tenir compte. Ce qui est annoncé ne se retrouve pas dans les plans des leçons. Aucune gradation de la difficulté n'est proposée. Il n'y 


\begin{tabular}{|c|c|c|}
\hline & & $\begin{array}{l}\text { a pas de prise en compte des besoins des élèves, car on } \\
\text { n'a aucune information sur eux. } \\
\text { - Il existe une certaine contradiction entre le contenu de } \\
\text { l'introduction générale qui souligne « une vision claire, } \\
\text { ni orientale, ni occidentale» (p.3) et l'introduction de } \\
\text { ce manuel qui affirme que le programme se base sur des } \\
\text { exercices suédois. }\end{array}$ \\
\hline Nuages de mots & Dénoté/description & Connoté/sens \\
\hline 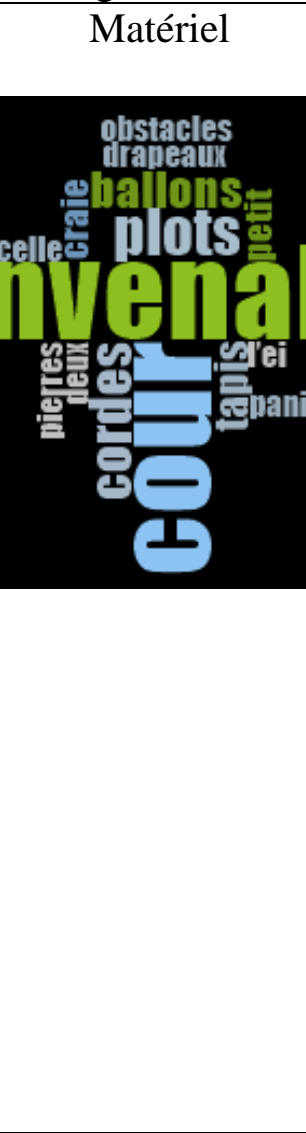 & $\begin{array}{l}\text { - De la page } 8 \text { à la page } 24 \text { du manuel, les textes sont con- } \\
\text { sacrés à la présentation typique des } 17 \text { leçons, comme } \\
\text { mentionné dans l'introduction du livre. Chaque leçon } \\
\text { débute avec la liste du matériel à utiliser pour la présente } \\
\text { leçon. } \\
\text { - Le mot cour est toujours associé au mot convenable } \\
\text { - Le groupe de mot qui revient le plus souvent est « cour } \\
\text { convenable» (17). } \\
\text { - Le groupe de mots les plus utilisés regroupe plots (6), } \\
\text { cordes (5), ballons (4) } \\
\text { - Un second groupe de mots regroupe tapis (3), craie (2), } \\
\text { petit (2) } \\
\text { - Un troisième groupe de mots cités une fois : deux, dra- } \\
\text { peaux, ficelle, l'EI, obstacles, paniers, pierres } \\
\text { - Mots associés : «drapeaux de l'ÉI» } \\
\text { - } 10 \text { types de matériel sont répertoriés : plots, cordes, bal- } \\
\text { lons, tapis, craie, drapeaux, ficelle, obstacles, paniers, } \\
\text { pierres }\end{array}$ & $\begin{array}{l}\text { - Le matériel est minime et simple. Dix types de matériel } \\
\text { différents sont répertoriés pour un manuel d'éducation } \\
\text { physique complet. } \\
\text { - En dehors des ballons, le matériel proposé est plus utile } \\
\text { à la démarcation du terrain, qu'à une potentielle manipu- } \\
\text { lation d'objet par l'élève ou même à sa condition phy- } \\
\text { sique. } \\
\text { - La majorité du matériel se trouve facilement, pas besoin } \\
\text { d'un «budget matériel ». Ceci implique que la leçon peut } \\
\text { être donnée dans un contexte où l'accès aux ressources } \\
\text { est limité, tel que les contextes de crise ou de guerre. } \\
\text { - Quant à la cour convenable, plusieurs questions se po- } \\
\text { sent: qu'entend-on par convenable? Fait-on référence à } \\
\text { un terrain semblable à celui de la couverture? Fait-on } \\
\text { simplement référence à un terrain non accidenté ou pro- } \\
\text { tégé ? Sur quels critères décide-t-on que la cour est « con- } \\
\text { venable»? Convenable est définit comme « qui est ap- } \\
\text { proprié à son objet » (Larousse) ou « qui est d'une qualité } \\
\text { suffisante (TLFi). L'utilisation du mot « convenable » } \\
\text { permet de garder un flou sur l'état attendu des infrastruc- } \\
\text { tures, qui reste donc à l'appréciation de l'enseignant. } \\
\text { Ceci laisse sous-entende que ces leçons ne se donnent } \\
\text { pas dans des écoles aménagées à cet effet. Ceci a-t-il un } \\
\text { lien avec un contexte où l'accès aux infrastructures de } \\
\text { qualité est limité, tel que les contextes de crise ou de } \\
\text { guerre ou avec les conditions géographiques de la région } \\
\text { ou bien des lieux de rassemblement de l'ÉI ? Est-ce dans } \\
\text { des montagnes ou bien des terres arides? }\end{array}$ \\
\hline
\end{tabular}




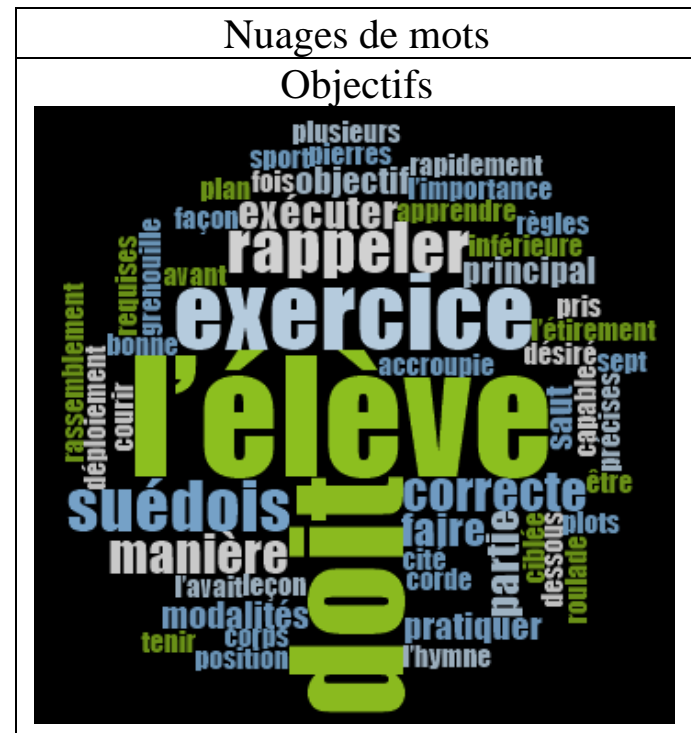

Dénoté/description « objectif » pour chacune des 17 leçons.

- Le groupe de mots qui revient le plus souvent est «l'élève doit» (16 objectifs sur 17$)$.

- Ce groupe de mots est suivi d'un verbe d'action: rappeler (6), exécuter (3), faire (3), pratiquer (2), être capable de courir (1), se tenir accroupie (1).

- Le mot le plus utilisé ensuite est «exercice» (10). Le mot « Suédois » (6) y est toujours associé pour former «L'exercice suédois », mentionné dans 6 objectifs sur 17.

- La notion de « se rappeler » est très présente (6)

- Un second groupe de mots se démarque : correcte (4), manière (4), exécuter (3), faire (3), partie (3)

- Le groupe de mots «de manière correcte » est employé à 4 reprises sur 17 objectifs.

- Dans un troisième groupe, des mots particuliers sont cités une fois: déploiement, hymne rassemblement.

\section{Connoté/sens}

- Dans le manuel, aucune mention ou distinction n'est faite entre les objectifs généraux et spécifiques. Les objectifs sont formulés en "l'élève doit" + verbe d'action. Ces verbes ont été organisé selon la taxonomie de Bloom, qui dit que les objectifs doivent couvrir différents niveaux cognitifs. Ces niveaux sont classés par ordre croissant de difficultés sur le plan cognitifs: connaissance, compréhension, application, analyse, synthèse et évaluation. Le verbe "rappeler" relève du niveau de la connaissance, le verbe "faire" relève du niveau de la compréhension et lesverbes "exécuter" et "pratiquer" relève du niveau de l'application. Deux objectifs concernent uniquement le domaine psychomoteur (courir et accroupir). Les objectifs visent des opérations cognitives dont la difficulté est peu élevée.

- Les objectifs ne sont pas SMART:

- Spécificité: les objectifs ne sont pas clairs en ce qui concerne le quoi, où, quand et comment. Ex. : « selon les modalités requises ».

- Mesurabilité: l'emploi du mot "correcte" laisse un flou. Il n'y a aucun critère de réussite ou de réalisation pour définir ce qui est « correcte » ou non. L'appréciation semble laissée à l'enseignant sans autre forme de mesure.

- Acceptabilité ou réalisme : les objectifs ne sont pas motivants, ne représentent pas un défi ambitieux et atteignable.

- Temporalité: les objectifs ne sont pas définis temporellement. Aucune distinction n'est faite en fonction de l'âge et les objectifs ne sont pas évolutifs. Il n'y a aucune gradation dans l'apprentissage.

- Plusieurs mots sont issus du registre militaire : «déploiement, rassemblement, précision ». La discipline est omniprésente dans le manuel. Dans la leçon numéro 2 qui découle de cet objectif, on peut lire : « ....afin que les élèves apprennent la discipline ». De plus, à chaque fin de leçon, il est mentionné «le retour dans le rang régulièrement $»$.

- Les objectifs des leçon 5, 7 et 11 ne sont pas en lien avec la partie principale mais avec la partie "jeu" de la leçon. Pourtant, les jeux sont présentés comme 


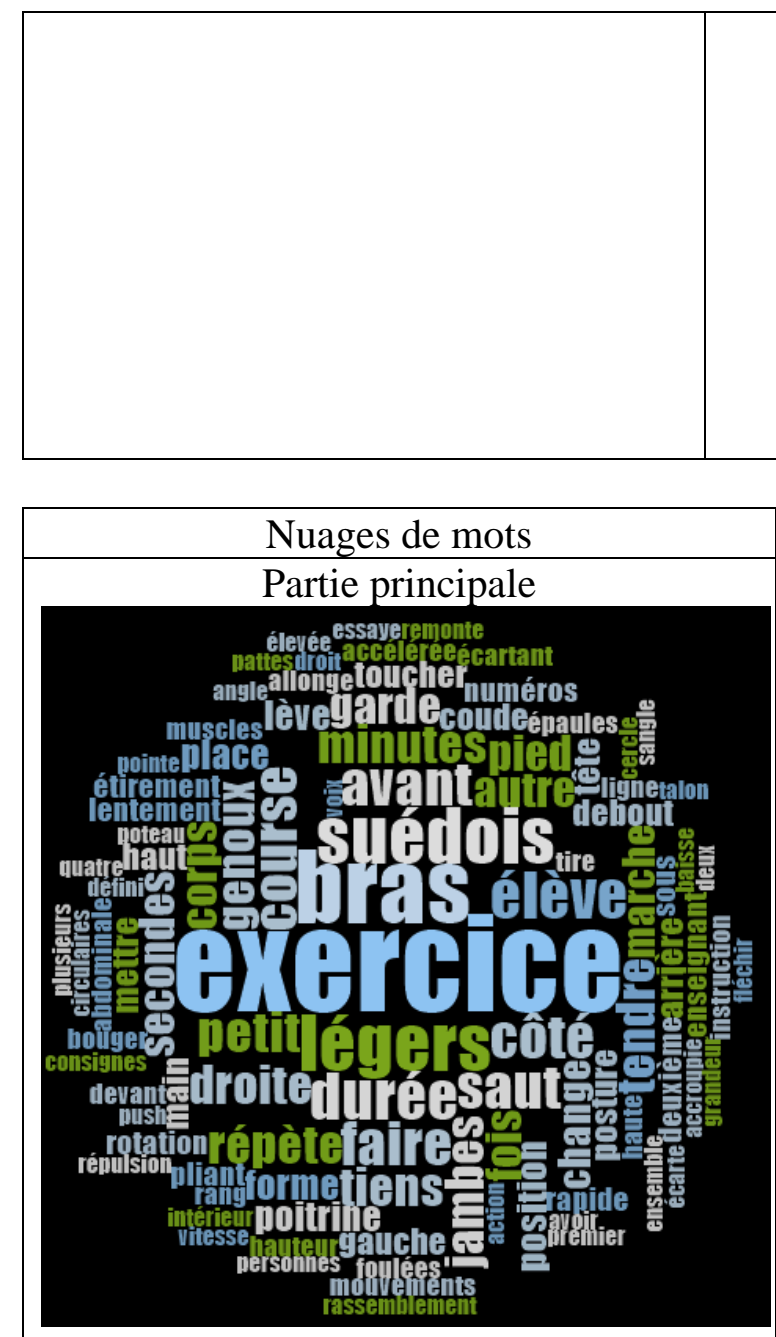

modulables contrairement aux parties principales. La logique voudrait que l'objectif soit directement lié à la partie principale et non au jeu. Cette structure est incohérente.

- L'objectif de la leçon 7 n'a aucun lien avec la préparation physique (voir analyse L6 versus L7).

- La référence continue à des exercices suédois, donc occidentaux, est en contradiction avec le désir, exprimé dans l'introduction du manuel, de s'éloigner du monde oriental et occidental pour n'être inspiré que par Allah et l'Islam.

- De la page 8 à la page 24 du manuel, la partie principale occupe le centre de la page de chacune des 17 leçons. Le texte est souvent accompagné par des illustrations en lien ou non avec le contenu [voir analyse sémiologique des illustrations du manuel];

- Le mot le plus utilisé est exercice [29] suivi de «bras» [21]. Le groupe de mots « exercice suédois » revient 15 fois

- Un premier groupe de mots se démarque : durée [12], élève [12], avant [11], course [11], côté [11], faire [11], saut [11], petit [10];

- Beaucoup de références au corps et à ses différentes parties : bras [21], genoux [9], jambes [9], corps [8], pied [8], poitrine [6] coude [5], main [5], tête [5], épaule(s) [5], abdominale [3], muscles [3], cheville [1], hanche [1], ischiojambiers [1], jambe [1], mollets [1];

- Peu de verbes actifs: faire [11], répète [9], tendre [9], tenir [9], garde [8], change [7], marche [7], mettre [5], saute [4], allonge [3], écarter [3], bouger [3], tire [3], essaye [3], baisse [2], fléchir [2] ;

- Mots particuliers cités une fois: Amir, déploiement, prince;

- Les verbes sont conjugués tantôt à l'infinitif et tantôt à l'impératif.
Comme le titre le mentionne, ce manuel vise la préparation physique et non l'éducation physique;

- Souvent une préparation physique appréhende une formation militaire et une participation active aux combats et à la guerre;

- Les exercices sont individuels. Il n'y a pas de coopération ou d'interaction entre les élèves [ex. : donner, attraper, etc.];

- La majorité des exercices consiste en des mouvements du corps (ex: exercices suédois). Il n'y a pas d'exercice plus moderne tel que lancer ou attraper des objets;

- Après l'exercice suédois [15 lecons sur 17], la course est l'exercice le plus mentionné [8/17], suivi du saut [6/17]. Des exercices tels que les pompes/push-up sont proposés alors qu'ils ne sont pas adaptés à des enfants d'âge primaire;

- Les verbes sont conjugués à infinitif ou à l'impératif. Cet ouvrage destiné à l'enseignant, alors pourquoi y trouvet-on des verbes à l'impératif? Cette utilisation du temps implique que les consignes à donner aux élèves sont déjà préparées dans le manuel. L'enseignant a peu de liberté pour adapter les savoirs et les rendre enseignable. 


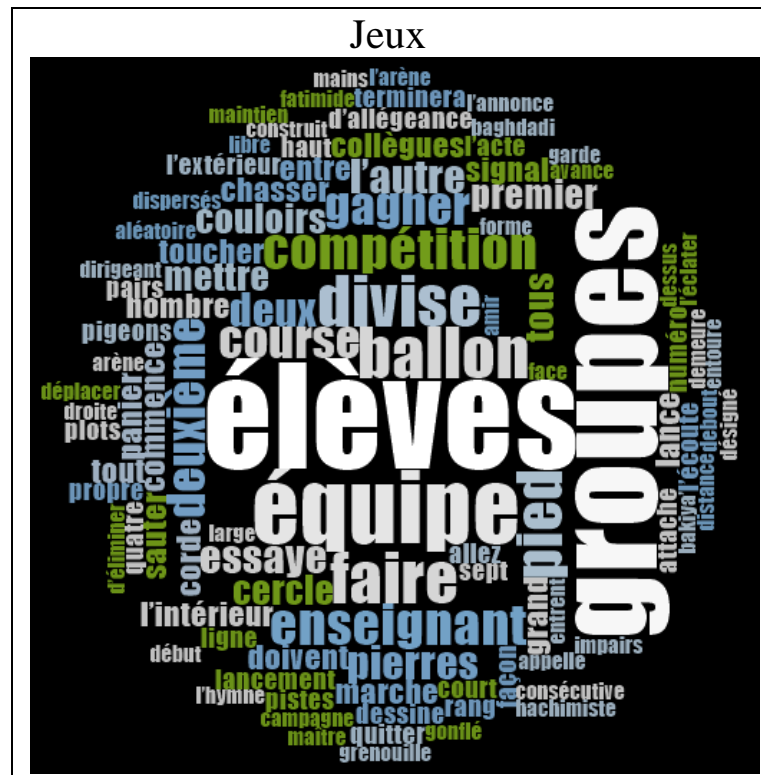

De la page 8 à la page 24 du manuel, chaque partie principale des 17 leçons se termine avec un «petit jeu».

Les mots les plus utilisés sont : élèves [21], groupes (20) et équipe (14).

Un second groupe de mots se compose de : enseignant [7], compétition [7], divise [9], ballon(s) [9], pied(s) [8] gagner [6], pierres [5], chasser [4].

Un troisième groupe de mots se distingue. On y trouve des références particulières telles que : collègues [3] allégeance [2], Amir [1], Fatimide [1], Hachimiste [1], hymne [1], maître [1], prince [1] Baghdadi [1]
Les jeux proposés sont destinés à mettre des groupes ou des équipes en compétition pour qu'à la fin, il y ait un gagnant. Ce principe de compétition apparait explicitement dans 14 leçons sur 17. Dans les trois autres leçons, l'idée de compétition est latente. Il y est question de division en groupe et de course entre les élèves. Les leçons 8 et 14 proposent le même jeu. Il n'est jamais question de jeux de coopération et aucune leçon ne mentionne l'interaction ou la coopération entre les élèves à d'autres fins que de gagner contre l'autre.

Encore une fois, certains termes ne sont pas à propos dans un manuel de préparation physique [allégeance, Baghdadi] et font directement référence à l'ÉI. Le jeu de la leçon 7 relève d'une tentative d'endoctrinement et de fidélité envers l'État.

- À la fin de chaque jeu, la même note ou encore remarque est mentionnée : «*Remarque : le jeu est une idée pour soutenir l'enseignant. L'enseignent peut donner plus de jeux aux élèves. ». Premièrement, il est légitime de se demander « qui est cet enseignant? ». Estil un militaire ? Ou bien un enseignant d'éducation physique ? Deuxièmement, dans un manuel qui est destiné à l'enseignant, où les consignes à l'attention des élèves sont écrites à l'impératif et n'ont qu'à être lues ou répétées, quelle est la limite de cette marge de manœuvre et cette liberté/flexibilité laissée aux enseignants? 
ANNEXE C - Analyse du contenu par nuages de mots: comparaison leçons 6 et 7

Ce tableau présente une comparaison de nuages de mots de deux leçons extraites du manuel: la leçon 6 et la leçon 7 . La leçon 6 a pour objectif : «L'élève doit rappeler l'importance des exercices suédois pour la partie inférieure du corps ». Cet objectif vise la préparation physique. La leçon 7 a pour objectif : «L'élève doit apprendre l'hymne cité ci-dessous ». Cet objectif est unique et très différent des autres leçons car il ne vise pas la forme physique, mais la récitation d'un hymne d'allégeance. Les mots-clés issus de l'analyse de la leçon 6 sont cohérents avec des mots qui se retrouveraient dans une "leçon" d'éducation physique. La partie principale de la leçon consiste, comme dans 15 leçons sur 17, à faire des mouvements du corps, nommés « exercices suédois ». Les exercices sont individuels, il n'y a pas d'interaction entre les élèves ou de coopération. Le matériel utilisé est très rudimentaire. Dans la partie jeu, comme dans 14 leçons sur 17, il est question de faire entrer des équipes en compétition pour qu'une équipe soit gagnante. L'objectif de la leçon 7, n'a aucun lien avec la préparation physique. Il s'agit d'apprendre un hymne et de le chanter en rang pour rendre hommage au leader de l'ÉI. Les mots-clés issus de l'analyse de la leçon 7 sont révélateurs de son objectif tacite qui relève de l'endoctrinement et de la formation de soldats de l'ÉI.

\begin{tabular}{|c|c|c|}
\hline Nuages de mots & Dénoté/ description & Connoté/sens \\
\hline 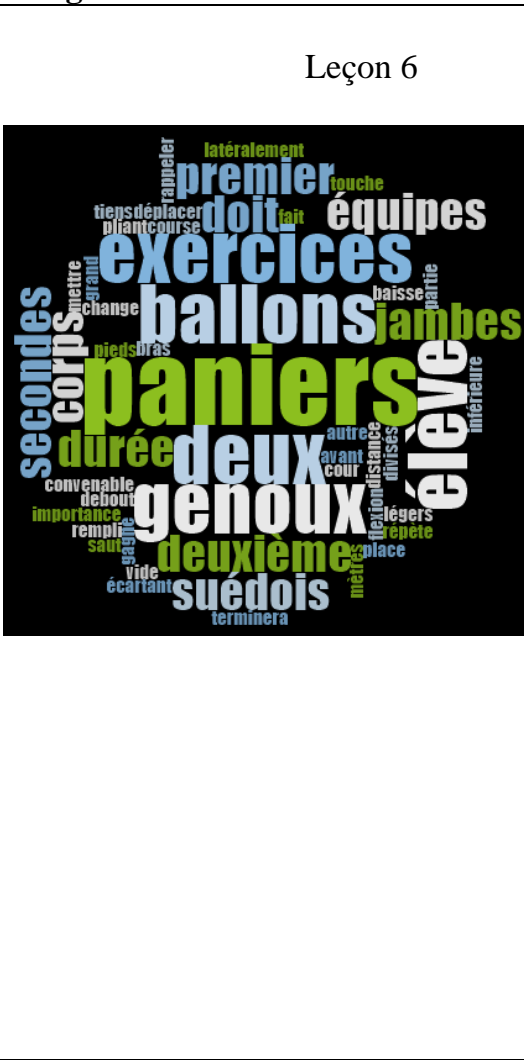 & $\begin{array}{l}-3 \text { groupes de mots: } \\
\text { - Les mots les plus utilisés sont paniers (4), bal- } \\
\text { lons (3), deux (3), exercices (3), genoux (3) et } \\
\text { élève (3). } \\
\text { Un second groupe de mots, cités deux fois se } \\
\text { démarque : corps, deuxième, doit, durée, } \\
\text { jambes, premier, secondes, suédois, équipes } \\
\text { Un troisième groupe de mots regroupe les } \\
\text { mots utilisés une seule fois } \\
\text { - Les verbes : cité deux fois : devoir (2). Cités une } \\
\text { fois rappeler, écarter, se tenir, faire, baisser, plier, } \\
\text { toucher, changer, répéter, diviser, mettre, dépla- } \\
\text { cer, terminer, gagner. } \\
- \text { Matériel: ballons (3), paniers (4) et cour (1) }\end{array}$ & $\begin{array}{l}\text { - L'objectif de cette leçon est assez typique du manuel } \\
\text { «l'élève doit se rappeler de l'importance des exercices } \\
\text { suédois pour la partie inférieure du corps ». } \\
\text { - Comme dans } 15 \text { leçons sur 17, la partie principale de la } \\
\text { leçon consiste à faire des mouvements du corps, nom- } \\
\text { més « exercices suédois ». Les exercices sont indivi- } \\
\text { duels, pas d'interaction ou de coopération entre les } \\
\text { élèves. } \\
\text { - Le matériel utilisé est très rudimentaire : ballons et pa- } \\
\text { niers. Le nombre de ballons à disposition doit supposé- } \\
\text { ment être élevé puisque le but du jeu est de transporter } \\
\text { les ballons d'un panier à un autre. Ce nombre n'est } \\
\text { pourtant pas spécifié et rend donc la faisabilité de ce jeu } \\
\text { incertaine. Comme toujours, la cour convenable est } \\
\text { mentionnée. } \\
\text { - Les verbes utilisés font référence à des actions indivi- } \\
\text { duelles. Les mouvements du corps sont privilégiés } \\
\text { (écarter, se tenir, baisser, plier, toucher). } \\
\text { - Dans le jeu, il est question de diviser les élèves en } \\
\text { équipes, de les faire entrer en compétition et qu'il y ait } \\
\text { une équipe gagnante. Ce principe de compétition appa- } \\
\text { raît explicitement dans } 14 \text { leçons sur 17. Dans les autres } \\
\text { leçons la compétition reste latente. } \\
\text { - Comme tout au long de ce manuel, les notions de rappel } \\
\text { et de répétition sont présentes et renvoient à l'idée d'en- } \\
\text { doctrinement. }\end{array}$ \\
\hline Leçon 7 & - 3 groupes de mots: & $\begin{array}{l}\text { - Dans le manuscrit, la leçon est divisée en deux parties: } \\
\text { une partie principale qui semble obligatoire et une }\end{array}$ \\
\hline
\end{tabular}




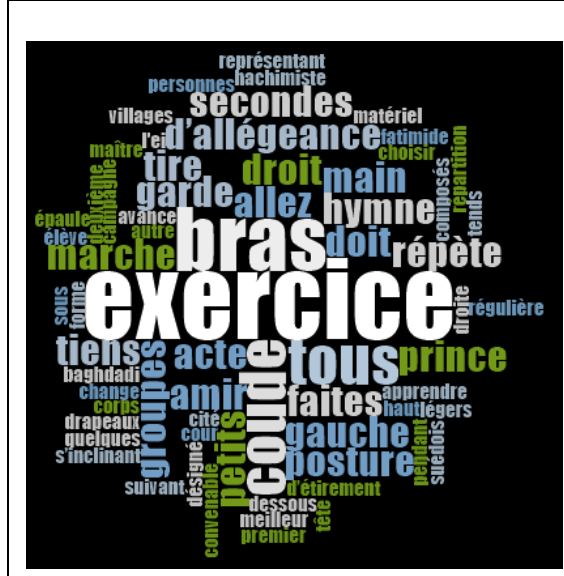

- Les mots les plus utilisés sont : exercice (5), bras (4), coude (3), tous (3)

- Un second groupe de mots, cités deux fois, se démarque : acte, allez, amir, doit, droit, d'allégeance, faites, garde, gauche, groupes, hymne, main, marche, petits, posture, prince, répète, secondes, tiens, tire

- Un troisième groupe de mots regroupe les mots utilisés une seule fois. Dans ce groupe de 40 mots, on note la présence de 8 mots particuliers : baghdadi, campagne, drapeaux, fatimide, hachimiste, l'ÉI, maître, villages

- Les verbes : cités deux fois : devoir, tirer, tenir, garder, répéter, marcher, aller, faire. Cités une fois : apprendre, choisir, changer, tendre, s'incliner, désigner, avancer.

- Matériel : cour (1) et drapeaux (1) partie “jeu”, décrite comme modulable par l'enseignant. L'objectif de cette leçon est lié à la partie «jeu». Il est incohérent que l'objectif soit relié à une partie modulable de la leçon et non pas à la partie obligatoire. L'objectif de cette leçon n'a aucun lien avec la préparation physique. Il s'agit d'apprendre un hymne et de le chanter en rang pour rendre hommage au leader, « le Baghdadi » (Abou Bakr al-Baghdadi est un djihadiste irakien, autoproclamé chef ou encore " Calife" de l'ÉI en 2014 après avoir été membre de Al-Qaida en Irak. Il a été responsable des plusieurs attaques terroristes dans de nombreux pays (Afrique du Nord, Asie, Europe, etc.). Il a été tué le 27 octobre 2019 lors d'une opération militaire américaine dans le nord-ouest de la Syrie, comme l'avait annoncé le président américain Donald Trump, et ce lors d'un assaut visant le chef de Daech).

La finalité d'enseignement de cette leçon est plutôt de former des soldats/disciples membres de l'ÉI.

- Le matériel nécessaire est, comme dans les autres leçons, une cour convenable et aussi des drapeaux de l'ÉI. Le texte ne décrit pas la manière dont les drapeaux sont utilisés. On suppose qu'ils sont utilisés lors de la « marche régulière » en groupe, accompagnée de la récitation de l'hymne. Dans cette leçon, les élèves font « une marche régulière avec un même rythme organisé », s'arrêtent et reprennent en suivant les instructions de l'enseignant. Cet exercice s'apparente fortement à une marche militaire ou un défilé dans un régime dictatorial. En effet, l'hymne proposé fait l'apogée du Baghdadi, chef de l'ÉI et ressemble à une propagande incitant les jeunes à lui jurer fidélité. Contrairement à l'introduction qui mettait Allah et le prophète en position centrale, cette position glisse vers le chef d'État dans cette leçon. On peut parler de propagande ou d'endoctrinement, car il est demandé aux enfants de répéter.

- On fait également référence au mot «Amir » utilisé pour désigner le leader, le commandant. Le groupe choisi lui-même son « Amir ». Encore une fois, l'organisation militaire est suggérée et soutenue par une illustration sur la même page du manuel. On y voit un 
